Круглов $A . H$. Памятные и юбилейные философские медали как визуальное средство и философский источник // Философия. ЖКурнал Высшей школы экономики. - 2021. T. 5, № 2. - C. 143-190.

\title{
АлЕКСЕЙ КРУГлОВ*
}

\section{ПАМЯТНЫЕ И ЮБИЛЕЙНЫЕ ФИЛОСОФСКИЕ МЕААЛИ КАК ВИЗУАЛЬНОЕ СРЕАСТВО И ФИЛОСОФСКИЙ ИСТОЧНИК ${ }^{* *}$}

Получено: 22.03.2021. Рецензировано: 06.04.2021. Принято: 15.04.2021.

Аннотация: В статье демонстрируется значение юбилейных и памятных философских медалей как особых визуальных средств для прояснения проблемных вопросов истории философии. Автор выдвигает тезис о том, что подобные медали способны облегчить восприятие философского учения, уточнить контекст его рассмотрения в конкретный момент времени и тем самым оказать серьезную помощь в качестве дополнительного исторического и философского источника. Однако они вряд ли способны помочь в толковании того или иного аспекта самого философского учения или отдельного высказывания конкретного философа. Обоснование тезиса представлено в виде разбора четырех философских медалей: медали в честь основания общества алетофилов (1740), медали А. Абрамсона в честь шестидесятилетия И. Канта (1784), медали А. Абрамсона на смерть И. Канта (1804), медали А. Л. Хелда в честь шестидесятилетия Г. В.Ф. Гегеля (1830). Если первые три медали помогают лучше понять философские черты немецкого Просвещения, причины обращения к словам Горация «sapere aude», своеобразие Канта как просветителя, философский смысл кантовской коперниканской революции и трансформацию восприятия «Критики чистого разума» в конце XVIII века, то надежды на четвертую медаль в прояснении гегелевской фразы о разуме, как розе на кресте современности и примирении с действительностью, оказываются напрасными. Кроме того, в ходе прояснения значения четырех вышеупомянутых медалей автор обращается также к памятной медали Хр. Вольфа Ж. Аасье (ок. 1733), медали на возвращение Хр. Вольфа в Халле И. Хр. Коха (1740) и медали на смерть Канта Ф. В. Лооса (1804).

Ключевые слова: юбилейные и памятные медали, sapere aude, Кант, коперниканская революция, «Критика чистого разума», Мендельсон, сова Минервы, Гегель.

DOI: $10.17323 / 2587-8719-2021-2-143^{-190}$.

Среди разнообразных вспомогательных исторических дисциплин почетное место занимает нумизматика, к предмету изучения которой относятся в том числе и разнообразные медали. Но если значение этой

*Круглов Алексей Николаевич, д. филос. н., профессор, Российский государственный гуманитарный университет (Москва), akrouglov@mail.ru, ORCID: oooo-0oo2-1152-1309.

** (C) Круглов, А.Н. (C) Философия. Журнал Высшей школы экономики.

Благодарности: статья подготовлена при поддержке РФФИ, проект № 20-011-0о227a, «Визуальное представление логического знания: о месте логики в когнитивных исследованиях». 
дисциплины для исторических штудий вряд ли ставится под сомнение серьезными учеными, то попытка применения элементов нумизматики в историко-философских исследованиях вызывает недоумение: какое значение те или иные медали могут иметь для философских учений и чем они вообще могут помочь в понимании философии того или иного мыслителя? Подобные сомнения частично оправданы и справедливы: при прояснении взглядов определенного философа медали и вправду вряд ли помогут. Однако если нас интересует восприятие, интерпретация, развитие того или иного учения, дело обстоит иначе. Нередко памятные и юбилейные медали, изготовленные на знаковые события, оказываются неким срезом, визуально запечатлевающим актуальные на конкретный момент времени образ, понимание и толкование философа. В качестве иллюстрации данного тезиса ниже будет представлено истолкование нескольких юбилейных медалей, в котором будет обосновано их философское значение.

\section{1. КАНТ И ПРОСВЕЩЕНИЕ: SAPERE AUDE}

Одним из самых популярных произведений Канта и по сей день является его знаменитая статья 1784 года «Ответ на вопрос: что такое просвещение?». Зачастую ее представляют не только сугубо кантовским ответом, но и некоей квинтэссенцией всего общеевропейского Просвещения как исторической эпохи: «Sapere aude! - Имей мужество пользоваться своим собственным рассудком! Таков, следовательно, девиз Просвещения» (Кант, Арзаканьян, 1994b: 127; Kant, 1923: 35). Разумеется, не являлось и не является тайной, что «Sapere aude»это слова Горация (Гораций, Гинцбург, 1993: 293), а не Канта. Тем не менее до сих пор особенно в русскоязычном философском пространстве распространено мнение о том, будто само обращение Канта именно к словам римского поэта явилось новым и необычным объяснением эпохи Просвещения, не имевшим прецедентов среди просветителей.

Но как этот призыв Канта воспринимали его современники и насколько эта апелляция к Горацию им казалась новой и необычной? Вскоре после публикации ответа Канта Христиан Вильгельм Снелль, старший брат известного в России начала хІх века автора философских учебников ${ }^{1}$, сообщил, что стал победителем конкурса Академии

${ }^{1}$ Пятичастный «Начальный курс философии» Фридриха Вильгельма Даниэля Снелля был дважды переведен на русский язык А. С. Лубкиным, П. С. Кондыревым, а также А. М. Брянцевым. 
наук в Мюнхене, назначенного на 1783 год². В его передаче конкурсное задание звучало так:

Как следует использовать изречение Горация Sapere aude для того, чтобы отсюда вытекало благо не только для каждого отдельного человека, но и для целых государств? (Snell, 1790: Vorrede. Б. п.)

Работа Снелля была опубликована через несколько лет после окончания конкурса, причем уже в измененном виде, а именно «с постоянным учетом кантовской моральной философии».
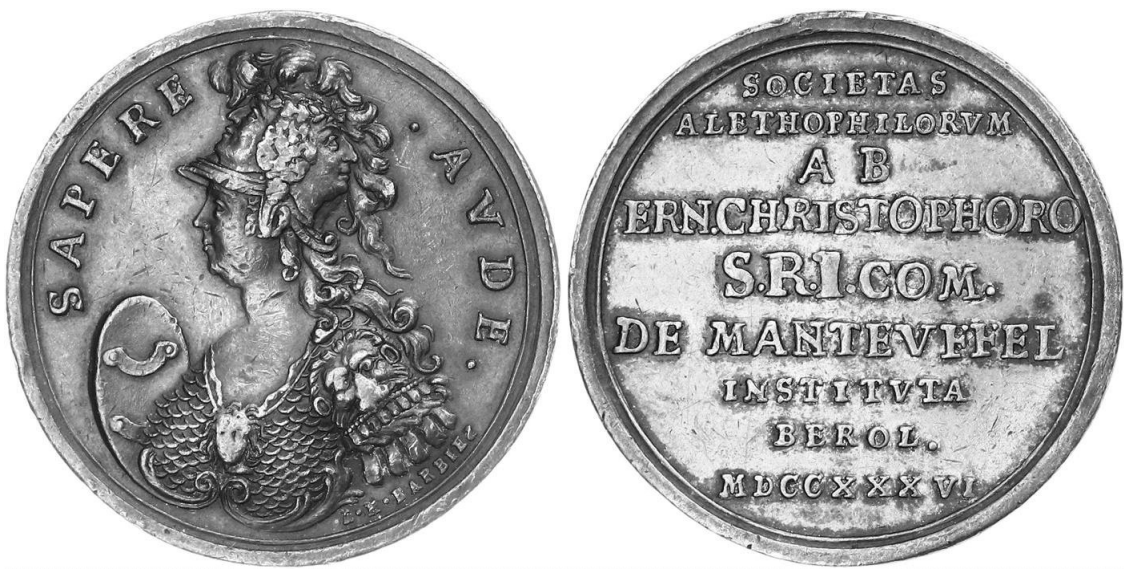

Илл. 1. Медаль общества алетофилов. 1740 год (Köhler, 1740: 369 .

23. November). Чеканка Л. Г. Барбица (Verzeichniß einer Sammlung vorzüglich schöner..., 1784: 189, № 655$)^{3}$.

Однако Снелль или авторы конкурсного задания на 1783 год не были первыми. Наглядным подтверждением этому служит медаль основанного в 1736 году общества любителей истины - так называемых «алетофилов» («Hexalogus Alethophilorum»..., 2011: 91-92):

на её аверсе был изображен поясной портрет Минервы, на шлеме которой под лавровым венком можно было видеть лица Лейбница и Вольфа в виде двуликого Януса с глубокомысленной надписью: sapere aude! (Wuttke, 1841: 35) (см. илл. 1).

${ }^{2} \mathrm{Cм}$. объявление о конкурсе: Berichte der allgemeinen..., 1783: 54 .

${ }^{3}$ См. о различных вариантах чеканки и различных медальерах, изготовлявших медаль (Berliner Blätter, 1870: 193-194. № 34-36; Rizzini, 1892: 184. № 11959). 


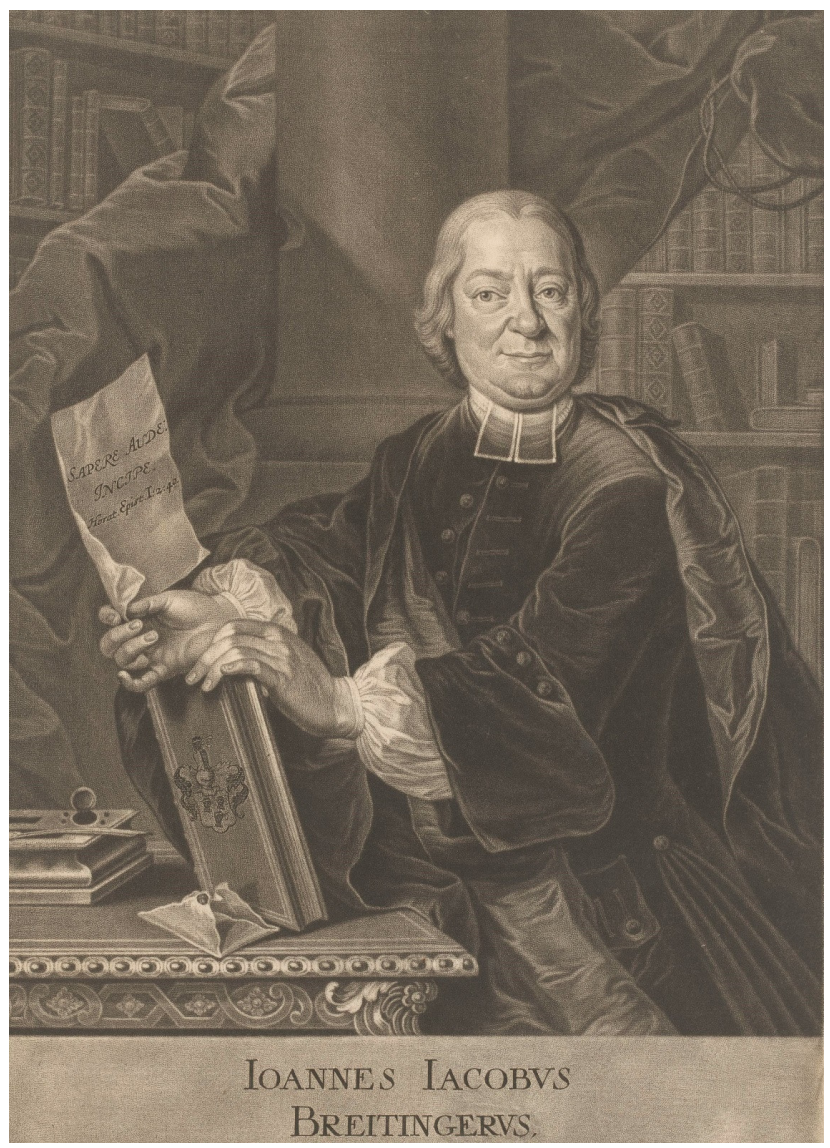

Илл. 2. И. Я. Брейтингер. Портрет работы И. Я. Хайда (Brucker, 1748: Б. п.).

В профессиональном описании этой медали перевод Горация на немецкий был дан в виде «Отважься быть разумным» (Köhler, 1740: 369 . 23. November $)^{4}$. Как раз в 1736 году это изречение было реактуализи-

${ }^{4}$ Cp. также (Kundmann, 1741: 769. Tabelle Xxviı. № 124). Подобный перевод был предложен в сочинении (Nachricht von der zu Berlin auf der Gesellschaft..., 1740: 4). См. обширные цитаты из этого сочинения (Wahrheitliebende Gesellschafft, 1747: 951). На реверсе медали значится, что общество алетофилов основано имперским графом Священной Римской империи Эрнстом Кристофом фон Мантойффелем в Берлине в 1736 году. 
ровано швейцарским профессором классической филологии Иоганном Якобом Брейтингером в учебнике логики, в котором предисловие завершается лозунгом «Sapere aude! Incipe!» (Breitinger, 1736: Vorrede. Б. п.). Современники настолько прочно связывали эту фразу Горация с Брейтингером, что на его портрете в иллюстрированном издании 1748 года профессор изображен с листом в руке, на котором как раз и запечатлена цитата из римского поэта (см. илл. 2). На медали, отчеканенной в $174^{\circ}$ году, это же изречение обществу алетофилов предложил использовать немецкий спинозист Иоганн Георг Вахтер, после чего оно многократно употреблялось также философом и писателем Иоганном Кристофом Готтшедом (см.: Scholz, 2014: 36-37).

Переписка четы Готтшедов с основателем общества алетофилов Эрнстом Кристофом фон

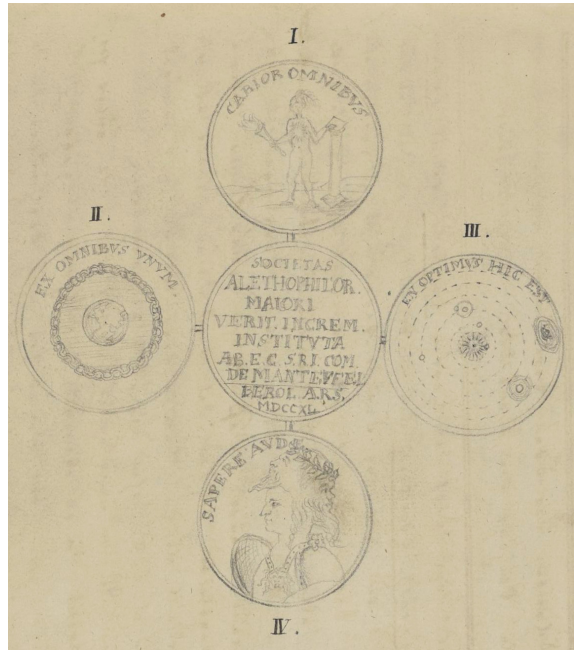

Илл. 3. Наброски И. Г. Вахтера к медали общества алетофилов. Январь 1740 года (Sammlung auserlesener Sendschreiben, 1739-1740: 341; L. A. V. Gottsched, 2012: 288. № 140).

Мантойффелем позволяет реконструировать процесс создания медали. Вахтер изначально предложил четыре варианта (см. илл. 3) (L. A. V. Gottsched, 2012: 289. № 140):

№ 1 должен представить истину, держащую факел, и стоящую рядом с ней колонну, как знак устойчивости. № 2- это глобус, окруженный цепью. № 3 есть коперниканская система мира. И № 4: голова Минервы с головами Сократа и Платона, как они присутствуют на некоторых геммах. Девиз этого последнего наброска -из Горация, в других же [трех] случаях иные цитаты из поэтов проф. Вахтеру представляются слишком длинными ${ }^{5}$.

${ }^{5}$ См. также сравнение Сократа и Платона с Лейбницем и Вольфом при описании медали (J. C. Gottsched, 1755: 104). 
Из этих четырех вариантов Мантойффель остановился на последнем, предложив заменить Сократа и Платона на Готфрида Вильгельма Лейбница и Христиана Вольфа ${ }^{6}$.

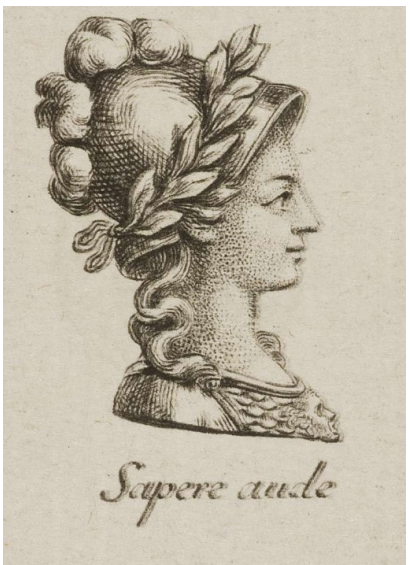

Илл. 4. Поясной портрет Минервы. Гравюра Д. Ходовецкого из календаря на 1780 год (Königl. grosbr. ..., 1780 : Б. п. $)^{7}$.

Таким образом, медаль алетофилов демонстрирует, что само обращение к фразе Горация было общим местом немецкого Просвещения (см. также илл. 4$)^{8}$ и ни самому Канту, ни его современникам не приходило в голову видеть в этом новизну и оригинальность. Наоборот, Кант обратился к широко известному и распространенному в его время тезису авторства Горация, и все та же медаль общества алетофилов заставляет воспринимать кантовскую статью о просвещении именно в этом свете. И если нас интересует своеобразие кантовского ответа, то его следует искать не в самом обращении к Горацию, а в том, какую трактовку у него обретают слова римского поэта. Уже сам перевод латинского изречения на немецкий язык ${ }^{9}$ показывает существенные смысловые разночтения:

${ }^{6}$ Идея Мантойффеля изменить единственное число в изречении на множественное осуществлена не была.

${ }^{7}$ См. описание (Engelmann, 1857: 166. № o8).

${ }^{8}$ Начиная с французского перевода Вольфа все того же 1740 года аверс медали алетофилов регулярно появлялся на титульном листе многих философских произведений (см.: Wolff, Des-Champs, 1740) (см. илл. 5). Комичным образом тем, кто меньше всего понимал смысл фразы Горация применительно к Просвещению, оказался сам Вольф, как это следует из его переписки с Мантойффелем и расспросов на эту тему (см.: Von Wolff, 2019: 298, 315, 324, 334).

${ }^{9}$ См. разные варианты перевода на русский: «Тот уж полдела свершил, кто начал: осмелься быть мудрым / И начинай» (Н. С. Гинибург); «На половину успел, кто начал; решись здравомыслить. / Только начни» (А. А. Фет); «Полдела уж совершил, кто начал. Осмелься / в добродетели вступить путь: начни...» («В латинском стоит: Sapere aude, осмелься смыслить, осмелься учинить себя мудрым, благоразумным, благонравным. Нужно благодушие, приличное дерзновение тому, кто любомудрие приобресть ищет, чтоб за встречающимися в пути затруднениями не унывал и не отстал своего намерения: для того Гораций говорит осмелься», А. Д. Кантемир); «Дерзай, начни, прими премудрости зерцало!» (А. Ф. Мерзляков). Варианты приводятся по собранию Г. М. Севера (см.: Север, 2008-2016). 
«Отважься быть разумным» («Erkühne dich vernünfftig zu seyn») в среде алетофилов;

«Отважьтесь быть благоразумными» («Erkühnt euch, [...] klug zu seyn») у Готтшеда (J. C. Gottsched, 1968: 201);

«Собери только свое мужество быть мудрым!» («Fasse nur den Muth weise zu seyn!») у Снелля (Snell, 1790: 412);

«Имей мужество пользоваться своим собственным рассудком!» («Habe Mut, dich deines eigenen Verstandes zu bedienen!») у Канта;

«Отважься быть мудрым» («Erkühne dich, weise zu seyn») у Фридриха Шиллера (Шиллер, Радлов, 1957: 273; Schiller, 1795: 40).

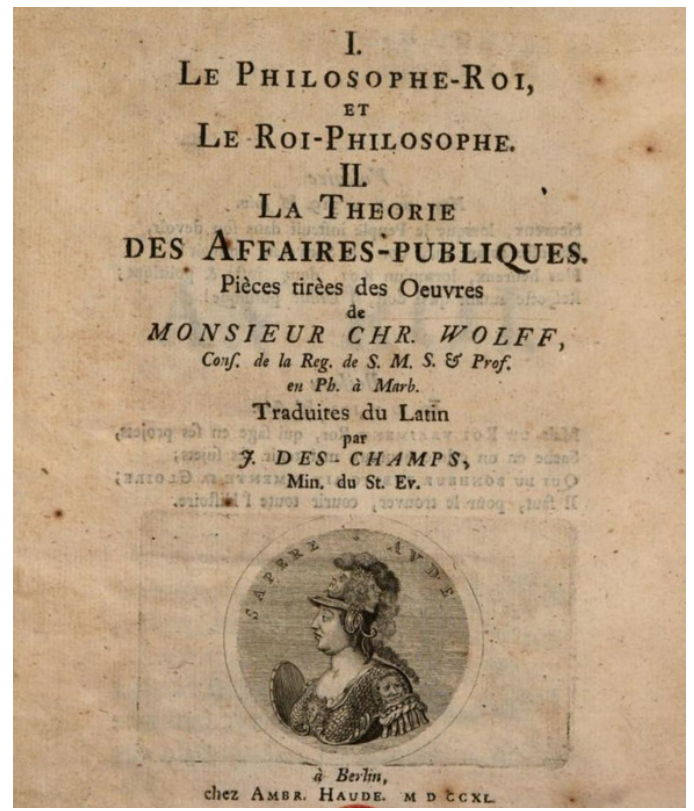

Илл. 5. Титульный лист издания Wolff, Des-Champs, 1740.

Среди всех современников лишь Кант явным образом связал слова из «Посланий» Горация с проблемой освобождения человека от чужеродного принуждения, придав широко известному юридическому понятию несовершеннолетия глубокую философскую и теологическую трактовку, в чем и состояло своеобразие кантовского ответа. И медаль общества алетофилов позволяет это сегодня лучше понять. 


\section{2. КОПЕРНИКАНСКАЯ РЕВОЛЮЦИЯ В ПЕРВОМ ИЗДАНИИ «КРИТИКИ ЧИСТОГО РАЗУМА» $(1781)$}

В наши дни одним из основных достижений Канта представляется его так называемая коперниканская революция, совершенная кенигсбергским философом в «Критике чистого разума». Но поскольку современные издания этого трактата носят гибридный характер-в их основу положено второе издание 1787 года, однако с отклоняющимися дополнениями первого издания 1781 года,- лишь самые пытливые читатели осознают, что кантовское сравнение с Коперником возникло только в предисловии ко второму изданию (см.: Kant, 1911a: B XVI-XVII; Кант, Лосский, Арзакньян и Иткин, 1994а: 18). Воспринимали ли кантовские современники кенигсбергского мыслителя неким Коперником в философии с момента публикации «Критики чистого разума»? Кем он являлся для них до публикации второго издания? Обращение к философским источникам того времени не позволяет однозначно и недвусмысленно ответить на этот вопрос. Но если изучить историю чеканки юбилейной медали к шестидесятилетию Канта в 1784 году (см. илл. 6), никаких сомнений относительно сформулированных вопросов не останется.
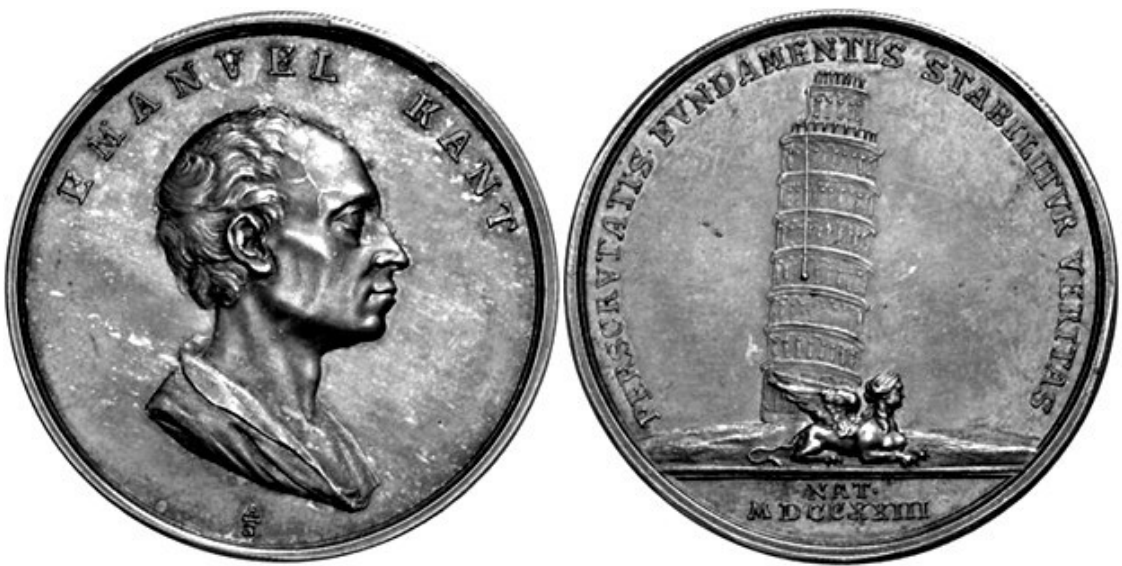

Илл. 6. Юбилейная медаль к шестидесятилетию И. Канта 1784 года. Чеканка А. Абрамсона (Schubert, 1842: фронтиспис; Vaihinger, 1898: 109).

Преподающий в университете Кенигсберга уже почти три десятка лет, причем почти полтора десятка лет в должности профессора, Иммануил 
Кант, только что опубликовавший свою «Критику чистого разума», отмечал в апреле 1784 года свое шестидесятилетие. По этому поводу группа его слушателей и друзей решила преподнести философу подарок, отчеканив юбилейную золотую монету. Главным автором смыслового оформления медали выступил один из наиболее значительных мыслителей кантовской эпохи Моисей Мендельсон, описавший 18 ноября 1783 года в письме хорошо знавшему Канта Марку Герцу, бывшему оппонентом на защите кантовской габилитационной диссертации, идею медали следующим образом (Mendelssohn, 1977: 160-161. № 620):

Вероятно, Вы припомните из обычных компендиумов теоретического естествознания одну такую башню, которая должна стоять в Италии (мне кажется, в Пизе). Она кажется стоящей не перпендикулярно, и тем не менее она обладает, в соответствии с правильными математическими основаниями, всей задуманной прочностью ${ }^{10}$. K этому отсылает моя легенда. Лицевая сторона. Портрет г-на Канта с подписью: N. N. Кант, родился... Оборотная сторона изображает упомянутую башню, кажущуюся готовой обрушиться. С нее свисает лот, отвес которого достигает земли и указывает на перпендикулярность башни. У подножия башни видно немного разбросанной земли и камней, чтобы исследовать основание. Надпись: Угрожает, но не падает. Через отступ: Критика чистого разума. Вопрос в следующем: не поймет ли наш друг аллегорию ложным образом и не обвинит ли нас в том, что мы захотели устроить сатиру на его Критику? Вы знаете его и знаете, мнителен ли он.

Опасения Мендельсона были не совсем беспочвенны. И хотя ответ Герца, похоже, не сохранился, можно предположить, что он порекомендовал внести в «легенду» существенные изменения. Разделял ли Кант мнение Мендельсона о задуманной кривою башне в Пизе-сказать затруднительно: насколько я могу судить, философ нигде не высказывался о ней в печатных работах и рукописном наследии. Сегодня можно только спекулировать о том, какова бы была реакция Канта на надпись «Угрожает, но не падает», однако многое говорит в пользу того, что она была бы гневной. Не удается установить и то, знали ли Мендельсон и Кант о легенде, согласно которой в Пизанской башне осуществлял свои опыты с падающими шарами Галилео Галилей, или же по меньшей мере об аргументе башни в его сочинении «Диалог о двух главнейших си-

10Эта же странная мысль Мендельсона о том, будто Пизанскую башню специально построили падающей, воспроизводится и в «Лексиконе немецких художников»: кантовская медаль изображает «построенную кривою башню в Пизе» (Meusel, 1808: 5). 
стемах мира» ${ }^{11}$. В любом случае некоторые современные исследователи толкуют изображение башни на медали как намек на Галилея, который своими опытами с падениями тел с Пизанской башни совершил для естествознания Нового времени то же, что и Кант своим критицизмом для философии Нового времени (см.: Essers, 1974: 51) ${ }^{12}$. Правда, имелись и иные объяснения башни: в ближайшем кругу философа некоторые толковали ее ни много ни мало как Вавилонскую башню (Kantiana..., 1860: 55 $)^{13}$. Вряд ли такая аллегория вызвала бы радость у Канта.

Окончательный вариант медали, отчеканенной знаменитым берлинским мастером-медальером Авраамом Абрамсоном, отличался от того образа, который обсуждали Мендельсон и Герц. Если лицевая сторона с профилем, выполненным на основе портрета работы кенигсбергского художника Пауля Генриха Коллина, и именем философа ( Emanvel Kant») практически не претерпела изменений- только год рождения («Nat. MDCCXXIII») перекочевал на оборотную сторону, то сама оборотная сторона была сильно изменена. «Критика чистого разума» здесь не упоминается вовсе, а вместо изречения про падающую башню появилась глубокомысленная латинская фраза «Perscrutatis fundamentis stabilitur veritas» («Исследованием оснований упрочивается истина»). Идею аллегории и надписи сам Кант приписывал Мендельсону (см.: Kant, 1922c: 368-369. № 223). Криво стоящая башня, с высоты которой был опущен отвес, а у фундамента которой расположился сфинкс, в точности воспроизводила первоначальную «легенду» Мендельсона.

Медаль была торжественно преподнесена Канту 3 марта 1784 года, т. е. более чем за месяц до юбилея, сразу по окончании семестра. О сборе денег, о процессе вручения и других деталях этого события поведал его участник Михаэль Фридлэндер (см.: Friedländer, 1805: 398-400).

\footnotetext{
${ }^{11}$ Кант говорит лишь об экспериментах Галилея с шарами на наклонных поверхностях (см.: Kant, 1911a: В хII; Кант, Лосский, Арзакньян и Иткин, 1994а: 6).

${ }^{12}$ Критику подобной интерпретации см. еще ранее Vaihinger, 1898: 111.

${ }^{13}$ Еще более экзотическое объяснение гласило, будто Кант получил медаль в подарок от еврейской общины за разъяснение некоторых трудных мест в Талмуде (см.: Wasianski, 1993: 218-219). Э.А.К․ Васиански в анкете 1804 года специально подчеркнул, что медаль была отчеканена не еврейской общиной в Берлине, а кантовскими слушателями, среди которых было немало еврейских студентов (см.: Kantiana..., 1860: 54). Попытался развеять эти слухи и М. Фридлэндер (см.: Friedländer, 1805: 398-400). О подготовке к вручению медали см. также свидетельство Карла Людвига Пёршке (Kantiana..., 1860: $63)$. По всей видимости, источником этой истории явилось биографическое сочинение о Канте 1802 года, как это показал в свое время Э. Фромм (см.: [Mortzfeld], 1802: 109; [Fromm], 1898: 376).
} 
Местная ученая газета «Königsberger Gelehrten und Politischen Zeitungen» сообщила 8 марта того же года о том, что несколько слушателей торжественно вручили профессору медаль в знак их «исключительного уважения за его столь глубоко ощущаемые ими заслуги в исследовании истины» (цит. по: Kant, 1922g: 134). Согласно газете смысл медали разъясняет как раз латинское изречение на ней. О первой реакции философа на подарок можно судить по его письму Иоганну Шульцу от 4 марта 1784 года. В нем Кант просит разрешение представить адресату медаль,

эмблема которой относится к произведению, восприятие и влияние которого очень сильно зависят от той адаптации и разъяснений, которые Вы были вольны дать ему (Kant, 1922с: 368-369).

Кант рассказал, что узнал о медали слишком поздно, когда она была уже изготовлена, в противном случае он непременно бы отговорил своих слушателей от подобного замысла.

Но уже неделю спустя в устах кантовского приятеля Иоганна Георга Гамана звучат иные интонации:

Золотая медаль, которая была вручена проф. Канту в прошлую среду, указывает год его рождения 23-м вместо 24-го и имеет еще несколько мелочей, которые поубавили его радость в связи с оказанной ему честью (Hamann, 1965: 134$)^{14}$.

Вероятно, другими «мелочами» явились ошибка в написании имениа Кант придавал большое значение написанию своего имени именно в форме «Иммануил» (см.: Hasse, 1804: 21) - и не очень удачно получившийся портрет, если верить душеприказчику Канта и его биографу Эреготу Андреасу Кристофу Васиански (Kantiana..., 1860: 55). Правда, по свидетельству другого биографа Людвига Эрнста Боровски, портрет философа работы Коллина был как раз наиболее удачным (Borowski, 1993: 72). Возможно, проблема состояла в том, что Абрамсон изобразил профиль Канта на «римский лад», как о том сообщила все та же «Кенигсбергская ученая и политическая газета» (цит. по: Kant, 1922a: 134). Чем дальше, тем больше у Канта улетучивалась радость от медали. Когда Боровски показал ему некоторые наброски будущего жизнеописания, философ с присущим ему юмором оставил два комментария к описанию золотой медали: об оборотной стороне - «однако с ошибочно указанной датой рождения 1723 вместо 1724», а о башне - «но

${ }^{14} \mathrm{~B}$ более ранних изданиях переписки Гамана это письмо ошибочно включали в состав письма к И. Ф. Харткноху от 14 марта 1784 г. 
криво стоящая» (Borowski, 1993: 41 Anm.). Эту медаль Кант несколько раз передаривал (Kant, 1922f: 391; Kant, 1922a: 392), причем и в завещании он ее обозначал как медаль с неправильно указанной датой рождения (Kant, 1922f: 391).

Из письма к Шульцу становится очевидным, что Кант однозначно связывал медаль с «Критикой чистого разума», поскольку Шульц написал комментарий именно на это произведение (Schultz [Schulze], 1784; Шульц, Фохт, 2010). От двусмысленного образа башни Кант и в самом деле не был в восторге. Но весьма вероятно, что эта башня появилась на медали не на пустом месте. Через два года после выхода в свет первого издания «Критики чистого разума» Мендельсон писал 10 апреля 1783 года ее автору:

Вот уже много лет, как я умер для метафизики. Моя нервная слабость запрещает мне всякое напряжение. [...] Ваша «Критика чистого разума» является для меня также критерием здоровья. Когда я льщу себя мыслью, что набрался сил, я решаюсь приняться за это произведение, поглощающее все нервные соки, и я совсем не теряю надежду еще и в этой жизни смочь его полностью обдумать (Mendelssohn, 1922: 308. № 190 $)^{15}$.

Ответ Канта от 16 августа 1783 года гласил (Kant, 1922d: 270. № 166):

То, что Вы рассматриваете себя словно умершим для метафизики, в то время когда практически весь наиболее ученый свет кажется умершим для нее, меня не удивляет, не принимая даже во внимание здесь... ту нервную слабость. Но то, что на ее месте критика, которая занимается лишь тем, что исследует почву для ее здания, не может привлечь к себе Вашего проницательного внимания или же немедленно его от себя отталкивает, вызывает мое большое сожаление, но тоже меня не удивляет... (Kant, 1922е: $344^{-} 345$. № 206) ${ }^{16}$

Тем самым идея исследования почвы будущей метафизики, которую подразумевает как латинское изречение, так и картина разрытой земли и камней у подножия башни, высказана самим Кантом. Образ же башни, возможно, почерпнут Мендельсоном из предисловия к кантовским «Пролегоменам» (1783) (Kant, 1911b: 256; Кант, Соловьев, 1994c: 7):

Ведь человеческий разум столь склонен к созиданию, что уже много раз он возводил башню, а потом опять сносил ее, чтобы посмотреть, как можно было бы лучше заложить ее фундамент.

15 Двумя годами позднее Мендельсон сообщит о своей «нервной слабости» уже в печатном произведении (см.: Mendelssohn, 1786: Vorbericht. Б. п.).

${ }^{16} \mathrm{Cp}$. также кантовское письмо мая 1781 года: «То, что господин Мендельсон отложил мою книгу в сторону, мне неприятно, но я надеюсь, что это случилось не навсегда». 
То, что Мендельсон, несмотря на жалобы на собственную «нервную слабость», вполне мог прочитать предисловие «Пролегоменов» «все перемалывающего Канта» (Mendelssohn, 1786: Vorbericht. Б. п.), вполне вероятно. Быть может, в мендельсоновских «Утренних часах» находится и продолжение диалога с Кантом ${ }^{17}$, в котором медаль была одной из визуальных «реплик»: «Это дело стоит предоставить лучшим силам, глубокомыслию Канта, который, надеюсь, с тем же духом, с каким он разрушал, будет заново строить» (ibid.: Vorbericht. Б. п.). При желании в «Критике способности суждения» (1790), т. е. уже через четыре года после смерти Мендельсона, можно усмотреть запоздалый ответ Канта на его замечание:

...если такой системе когда-нибудь суждено осуществиться под общим названием метафизики..., то критика заранее должна исследовать почву для этого здания до той глубины, на которой залегает первое основание способности [давать] независимые от опыта принципы, дабы не осела какая-нибудь часть постройки, что неизбежно повлекло бы за собой обвал всего здания (Kant, 1913: 168; Кант, Мотрошилова и Длугач, 2001: 71-73).

Разнообразными интерпретациями оброс образ сфинкса на юбилейной медали. Если учесть то обстоятельство, что эпиграф к «Критике чистого разума» Кант взял из «Великого восстановления наук» Фрэнсиса Бэкона, то можно предположить, что речь идет о двадцать восьмой истории из «Мудрости древних» под заголовком «Сфинкс, или наука» (Бэкон, Федоров, 1972: 287-290). Боровски предполагал, что сфинкс охраняет фундамент башни (Borowski, 1993: 41). Патриарх кантоведения Ханс Файхингер, напротив, рассматривал сфинкса «как общеизвестный символ загадочности мира» (Vaihinger, 1898: 112; cp. также Dietzsch, 2010: 40). Отвес напоминал Файхингеру кантовское понятие путеводной нити, направляющей линии (Richtschnur), которая показывает отклонение метафизики от перпендикуляра (Vaihinger, 1898: 113). В целом же Файхингер толковал аллегорию Мендельсона так: «при помощи исследований Канта окончательно отменяется угрожающий обвал метафизики» (ibid.). C его точки зрения, такую трактовку подтверждало и сообщение Эмиля Фромма, рассматривавшего сочинение Джорджио Вазари в качестве источника Пизанской башни для Мендельсона (Leben der ausgezeichnetsten Male..., 1832: 65-64). Фромм утверждал, будто кантовские предшественники, подобно архитекторам Пизанской башни,

${ }^{17}$ См. о пересылке «Утренних часов» Канту (Schütz, 1922а: 423. № 253). 
не смогли заложить подлинный фундамент метафизического здания, по причине чего оно и угрожает обвалиться. Кант же не только исследовал фундамент, но и укрепил его прочной стеной, в результате чего уже наклонившееся здание вновь стоит прочно ([Fromm], 1898: 377). Правда, и Фромм, и Файхингер не учитывали одного важного исторического обстоятельства - слов Мендельсона, подтвержденных «Лексиконом немецких художников», о том, что Пизанская башня будто специально была построена кривой. Вазари же, напротив, утверждал, что два мастера, строившие башню в Пизе, не имели достаточного опыта, а кривизна ни в коем случае не являлась результатом задуманного расчета.

Столь подробный разбор кантовской юбилейной медали 1784 года потребовался для того, чтобы показать: какие бы гипотезы и по сей день ни выдвигались для толкования ее смысла, с какими бы предшественниками и современниками Канта ее ни сопоставляли, будь то Бэкон или Галилей, одно имя при этом отсутствует напрочь - Николай Коперник. Ближайший круг слушателей, приятелей и друзей Канта, к которому принадлежал и мыслитель такого масштаба, как Мендельсон, с огромным трудом искал визуальный образ вышедшей за два года до этого «Критики чистого разума». И никому из них совершенно не пришло в голову сравнение с Коперником! Это тем более поразительно, что даже у Вахтера в 1740 году коперниканская система была одним из вариантов изображения для медали общества алетофилов. Для того же, кто совершил пресловутую коперниканскую революцию в философии, этого в 1783-1784 годах не предложил никто. А поэтому юбилейная медаль к шестидесятилетию Канта оказывается просто кричащим доказательством того, что без собственных кантовских слов во втором издании «Критики чистого разума» никакой коперниканский переворот, бывший вроде бы фактом уже и в первом издании, если это рассматривать задним числом, не оценивался бы как одна из главных характеристик кантовской критической философии. Неизвестно, возникло бы без самого Канта вообще его сравнение с Коперником, а если бы и возникло, насколько узок был бы круг его хождения.

Появление же кантовского сравнения с Коперником - случайный исторический эпизод. Реагируя на, как казалось Канту, чересчур хвалебную рецензию на собственное «Основоположение к метафизике нравов» $(1785)$ со стороны профессора красноречия университета Йены Христиана Готфрида Шютца, сравнившего «Критику чистого разума» с революцией в философии (см.: Riga, b. Hartknoch, 1785: 21; Schütz, 
1922b: 399. № 237; Kant, 1922b: 406. № 243; Schröpfer, 2003), Кант попытался несколько релятивизировать эту оценку во втором издании «Критики чистого разума». Здесь философ подчеркнул, что революции в науке не есть нечто невиданное, а суть периодически случающиеся необходимые процессы, и в качестве одного из примеров он и привел до того ни разу не упоминаемого во всех своих докритических произведениях Коперника. Смысл же собственного кантовского замысла выглядел теперь так (Kant, 1911a: B XVI; Кант, Лосский, Арзакньян и Иткин, 1994а: 18):

До сих пор считали, что всякие наши знания должны сообразоваться с предметами. ...Следовало бы попытаться выяснить, не разрешим ли мы задачи метафизики более успешно, если будем исходить из предположения, что предметы должны сообразоваться с нашим познанием...

Еще одним подтверждением высказанным выше оценкам кантовской юбилейной медали служат размышления Георга Кристофа Лихтенберга. Читая предисловие ко второму изданию «Критики чистого разума», Лихтенберг обнаружил для себя много примечательных мыслей (Lichtenberg, 1994: 737. J 569). Под впечатлением этого текста он заметил: «Было бы чем-то особенным, если истинная система философии, равно как и мироздания, обе появились бы из Пруссии» (ibid.: 723. J 473). Эти мысли Лихтенберг сообщил и напрямую Канту в письме 1791 года (Lichtenberg, 1922: 302. № 495):

...при появлении Вашей критики, как только я смог ухватить в ней столько, чтобы усмотреть, на что это все нацелено, я заявил как устно, так и письменно некоторым моим друзьям: смотрите, страна, которая дала нам истинную систему мира, дает нам еще и самую удовлетворяющую систему философии.

Конечно, курьезным фактом здесь оказывается то, что Лихтенберг, будучи профессором на тот момент «английского» университета Геттингена, записал Торунь и Коперника в Пруссию и пруссаки, причем еще почти за два столетия до возникновения самого королевства Пруссии, хотя в подобных взглядах он и был не столь одинок ${ }^{18}$. Важнее здесь другое - Лихтенберг, будучи профессором физики и автором биографии Коперника (см.: Lichtenberg, 1844), следующим образом высказался о юбилейной кантовской медали (Lichtenberg, 2007: 232-233):

${ }^{18}$ См., например (Schelling, 1860: 5; Шеллинг, Левина и Михайлов, 1989: 28; Rosenkranz, 1840: 99,131$)$. 
...я бы желал придать лучший аверс медали Абрамсона, Птолемеевская система на заднем фоне и в закате, а на переднем фоне Коперниканская система. И в любом случае господин Кант напротив Коперника.

Почему же эта очевидная мысль не пришла в голову Герцу и даже проницательному и глубокомысленному Мендельсону? Вероятно, она никогда бы не пришла и в голову Лихтенбергу, если бы он не прочитал предисловие ко второму изданию «Критики чистого разума», о содержании которого в 1784 году ничего не знало не только кантовское окружение, но и сам кенигсбергский философ.

\section{3. «КРИТИКА ЧИСТОГО РАЗУМА», СОВА И МИНЕРВА}

Все тот же берлинский гравер Абрамсон через двадцать лет после медали на шестидесятилетие Канта изготовил еще одну памятную кантовскую медаль - правда, теперь уже на смерть философа в 1804 году (см. илл. 7). Мендельсона, придумавшего легенду медали 1784 года, к тому времени уже давно не было в живых. На этот раз сюжет медали придумал Иоганн Фридрих Цёлльнер-тот самый священник, спровоци-
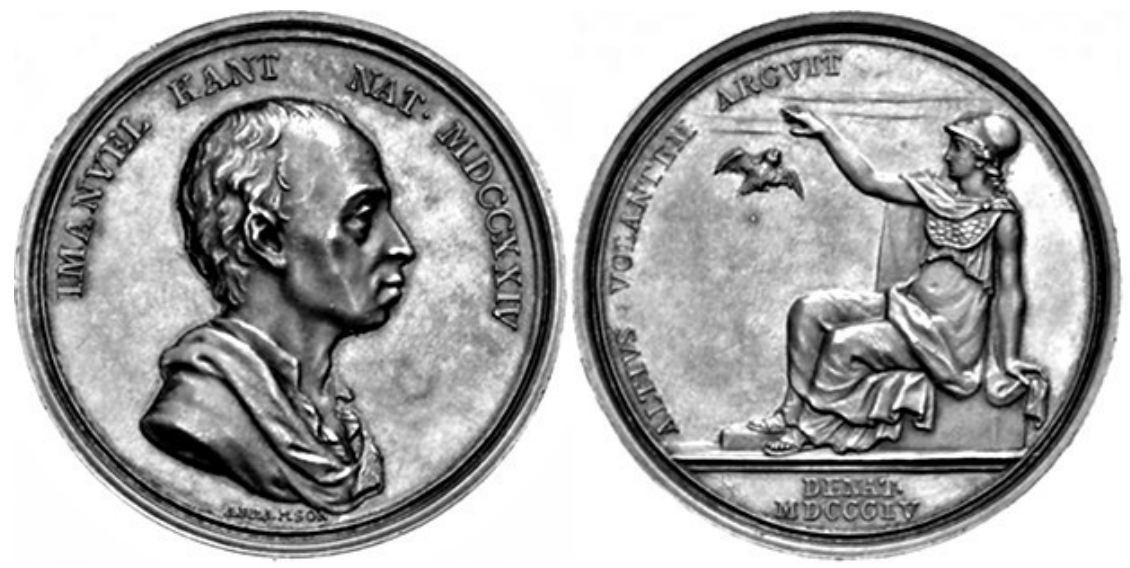

Илл. 7. Медаль на смерть И. Канта 1804 года. Чеканка А. Абрамсона (Schubert, 1842: фронтиспис; Immanuel Kant: Erkenntnis..., 2004: 220).

ровавший вопросом «Что такое Просвещение?» (Zöllner, 1783: 516) в 1783 году дискуссию, в которой приняли участие и Кант с его горациевским «sapere aude», и Мендельсон (Мендельсон, Волкова, 2011: 74-78). 
Медаль 1804 года прекрасно иллюстрирует, как за двадцать лет изменилось восприятие кантовской философии. На аверсе медали - все тот же портрет Канта, только, быть может, в чуть менее «римском» стиле, если только это не искажение копий. По мнению большинства современников, этот портрет Канта удался хуже предыдущего. В отличие от медали 1784 года и имя («Imanvel Kant»), и год рождения («Nat. MDCCXXIV») здесь уже указаны правильно. На реверсе указаны год смерти («Denat. MDCCCIV»), замысловатое латинское изречение «altius volantem arcuit», изображены женская фигура, сидящая на постаменте, а также летящая сова.

Иллюстрация на реверсе имеет разные толкования. Кантовский биограф Васиански излагал основную мысль медали так: «...исследовательский дух человека имеет определенные границы». Специально характеризуя реверс, он подчеркивал, что на нем

видят Минерву, богиню мудрости, опознаваемую по шлему и щиту, сидящую на кубе, на который она в то же время опирается левой рукой, что считается образом непоколебимой прочности. Правой же рукой она, напротив, препятствует полету ночной совы, образу пылкого влечения к исследованию, которая хочет взмахнуть к высоким далям, что выражает главный принцип этого философа. Еще отчетливее это становится благодаря удачной надписи старшего консисторского советника Цёлльнера: Altius volantem arcuit, т. е. она придерживает слишком высоко взлетающего (Kantiana..., 1860: 55).

В берлинском журнале 1804 года о реверсе медали сообщалось: на ней очень удачно была выражена мысль, что «Кант определил границы человеческого знания посредством спекуляций и доказал смехотворность предприятий по их перешагиванию», что было осуществлено при помощи «сидящей Минервы, которая вытянутой правой рукой отпугивает назад стремящуюся ввысь сову, с надписью: Altius volantem arcuit» (Miscellen, 1804: 244. 26. März).

Одна из самых экзотичных трактовок медали была дана в психологическом журнале 1858 года (Immanuel Kant..., 1858: 45):

Реверс созданной после смерти Канта медали изображает богиню Афину Палладу с летящей напротив нее совой и многозначительную надпись: altius volantem arcuit! Она осмысленно характеризует устремления мужа, который при известии о французской республике со слезами на глазах высказался нескольким друзьям в следующих словах: Ныне я могу, как когда-то старец 
Симеон, сказать: Владыко! Отпусти твоего раба с миром, после того как я видел день спасения! ${ }^{19}$.

K счастью, помимо различных спекуляций мы располагаем объяснением медали и со стороны самого автора латинского изречения Цёлльнера. Поскольку в печати было опубликовано ошибочное описание медали, уже тяжело больной Цёлльнер посчитал необходимым внести коррективы. В исходной заметке о медали утверждалось в стиле Васиански:

На оборотной стороне видят Минерву, сидящую на кубе, на который она опирается левой рукой (символ непоколебимой прочности). Правой рукой она препятствует полету ночной совы к высоким далям. Надпись, сочиненная господином пробстом Цёлльнером, гласит: Altius voluntatem arcuit (Künste, 1804: 483. 14. April).

В своем исправлении Цёлльнер указал на ошибку в приведенном латинском изречении, а также исправил его некорректный перевод на немецкий язык, данный в биографии Васиански («она придерживает слишком высоко взлетающего»): правильный авторский перевод звучит как «она препятствует ее слишком высокому полету». Что же касается самого изображения на реверсе, то его авторская трактовка такова:

Взмывающая вверх ночная сова... есть символ безудержной, выступающей за границы своей сферы спекуляции, Минерва - символ кантовской философии, которая возвращает ее в границы присущей ей области (Zöllner, 1804: 800. 23. Juni).

Куб, как постамент Минервы, символизирующий прочность, имеет ряд весьма примечательных прецедентов. Около 1733 года, т. е. будучи уже десять лет как изгнанным из Халле, Вольф-на тот момент профессор университета Марбурга - удостоился памятной медали, изготовленной швейцарским мастером Жаном Дасье (см. илл. 8). Она не была приурочена к какой-то специальной дате, а, скорее, впервые в столь отчетливой форме фиксировала то, что Вольф стал «всемирно известным философом нашего времени» (Köhler, 1740: 385. 7. Dezember). На аверсе был изображен «возвышенный» портрет Вольфа и было выбито его имя в латинской транскрипции, реверс же представлял собой изображение женской фигуры в тонком холсте, голову которой

${ }^{19}$ Автор статьи имеет в виду эпизод с библейским подтекстом, засвидетельствованный кантовскими современниками (см.: Varnhagen, 1843: 755; Лук. 2:29). 
украшала звезда. Дама сидит на кубе, который-в отличие от представленного на медали на смерть Канта - является именно довольно высоким кубом, а не призмой, и поддерживает правой рукой стоящий на этом же кубе рог изобилия, преисполненный фруктов, а левую руку выставляет в сторону. Куб же обвивает, проглотив свой собственный хвост, змея. Изображение сопровождала надпись «Sedes fructusque perennis» (см.: Götten, 1736: 740; Johann Peter Nicerons Nachrichten, 1760: 248; Laverrenz, 1887: 49. № 105).
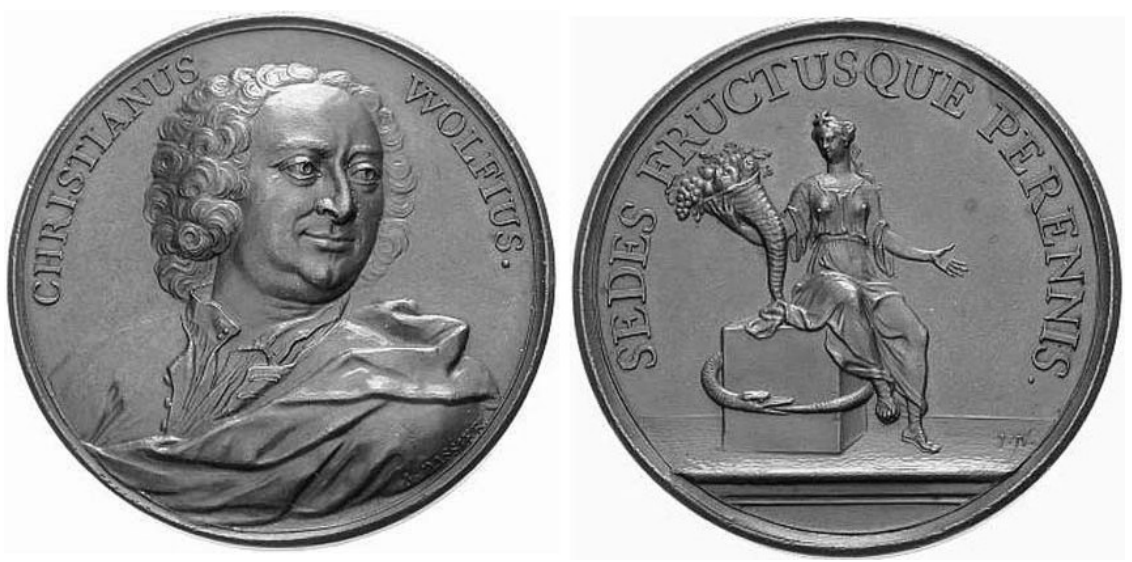

Илл. 8. Памятная медаль Хр. Вольфа ок. 1733 года. Чеканка Ж. Дасье (Ludovici, 1738: 352. § 490; Lesser, 1739: № 27. Б. п; Köhler, 1740: 385 . 7. Dezember; J. C. Gottsched, 1755: 104; Nilsson, 2013: 417. № 639).

Хотя женскую фигуру в описаниях порой и называли абунданциейбогиней изобилия - или фортуной, доминирующее толкование звучало все же иначе: речь идет о философии. И. Кр. Готтшед в биографии Вольфа подчеркивал, что рог изобилия «показывает разнообразные плоды философии во всех остальных науках», а куб и змея-«прочное основание и вечность ее истин, о чем сообщает надпись...» (J. C. Gottsched, 1755: 95). В современных Вольфу работах имелось несколько немецких переводов этого изречения: «Место и плод вечны» (Köhler, 1740: 385 . 7. Dezember) или «Ее местопребывание и ее плоды не уничтожает время» (Lesser, 1739: 119. § 193). Если бы на аверсе был изображен 
какой-либо иной современный Вольфу немецкий философ, а не он сам ${ }^{20}$, медаль не имела бы дополнительного подтекста и однозначно бы воспринималась в духе философии как прочного и плодотворного основания, не устраняемого ходом времени и привходящими обстоятельствами. Однако на медали был запечатлен именно изгнанный из Халле Вольф, и вопрос о его местопребывании, как и о местопребывании философии, приобретал в таком случае особую остроту: угрозой смертной казни философа Вольфа можно изгнать из университета, из города, из королевства, однако вечная философия со своими истинами этим затронута не будет и продолжит плодоносить. Эта мысль о вечности философии дополнительно подчеркивается отсутствием почти облигаторного указания на год чеканки.
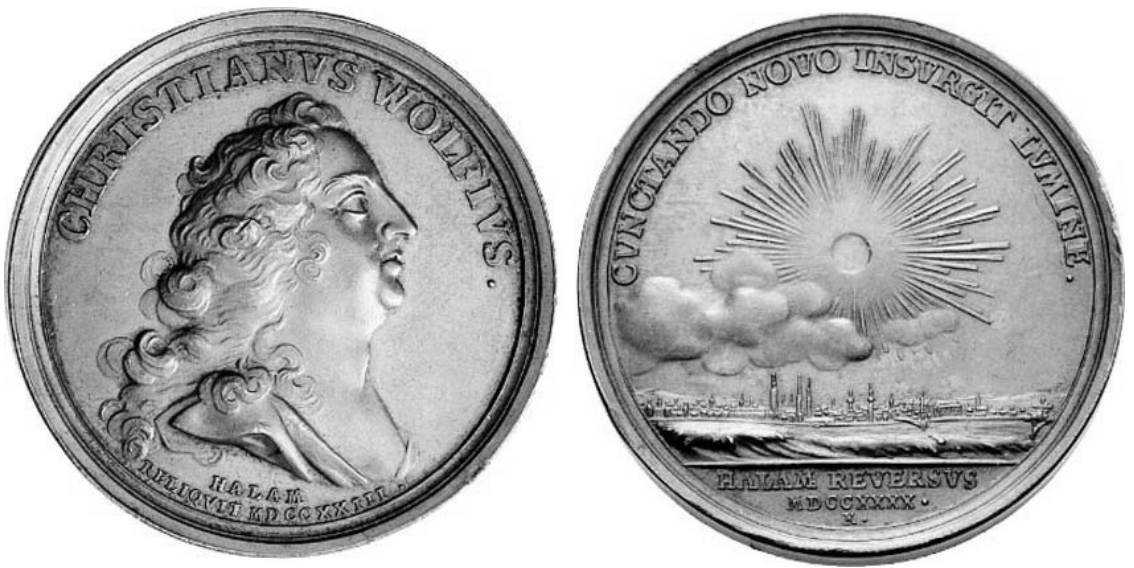

Илл. 9. Памятная медаль на возвращение Хр. Вольфа в Халле 1740 года. Чеканка И. Хр. Koха (Köhler, 1741: 409. 27. Dezember; J. C. Gottsched, 1755: 152; 300 Jahre Universität Halle..., 1994: 65)

Но если философия как таковая со своими истинами и пребывает в вечности, то эмпирически данные города и университеты зависят от физического местопребывания живых философов. Скачок с интеллигибельного куба медали 1733 года в чувственно воспринимаемый град Халле стал сюжетом для иной медали 1740 года знаменитого

${ }^{20}$ Справедливости ради стоит заметить, что позднее этот найденный на реверсе медали Вольфа сюжет Дасье эксплуатировал и в других своих работах, воспроизводя также на реверсе медали Цицерона (ок. 1740) и Дж. Селдена (ок. 1750). 
медальера из Готы Иоганна Христиана Коха (см. илл. 9). Она посвящена триумфальному возвращению Вольфа в город и университет, из которого он был изгнан. На аверсе помимо стилизованного портрета и латинизированного имени, как и на предыдущей медали, значилась латинская надпись «Halam reliqvit MDCCXXII»: покинул Халле в 1723 году (о причинах здесь ничего не сказано). На реверсе была изображена панорама города Халле с угадываемой церковью Св. Марии, над которой в небе яркое Солнце своими лучами разгоняло скопившиеся тучи. Латинская надпись внизу гласила: «Halam reversvs MDCCXXXX», вернулся в Халле в 1740 году (J. C. Gottsched, 1755: 115; Johann Peter Nicerons Nachrichten, 1760: 251-252; Laverrenz, 1887: 49). Над Солнцем и небом помещалось еще одно латинское изречение: «Cvnctando novo insvrgit lvmine», что в немецком переводе, современном медали, было передано так: «После задержки он восходит с новым светом» (Köhler, 1741: 409. 27. Dezember). Это изображение явным образом отсылало к многочисленным фронтисписам в философских произведениях Вольфа, в которых Солнце и тучи были одним из наиболее излюбленных просвещенческих сюжетов (см.: Schneiders, 1990: 83-93).

Местоположение и местопребывание «Критики чистого разума» на медали Абрамсона 1804 года особых вопросов не вызывает. Если сравнить ее с юбилейной медалью на шестидесятилетие кенигсбергского философа, то она демонстрирует существенные изменения в восприятии кантовской критической философии, произошедшие в последние десятилетия жизни философа. Если в 1784 году «Критика чистого разума» изображалась криво стоящей башней, к которой Кант прилагал отчаянные усилия, дабы помешать ее падению, то в 1804 году все та же «Критика чистого разума» уже есть прочнейший фундамент, символ непоколебимости, прочности и стойкости. В отличие от Минервы на медали алетофилов здесь Минерва изображена в полный рост, а Кант является не элементом ее шлема, а скорее ее олицетворением. Похоже, что все той же «Критикой чистого разума» вдохновлялся Цёлльнер и в выборе совы, хотя он и преобразовал в нее иную птицу. Кант практически полностью игнорировал в своих произведениях сов, зато у него есть впечатляющий образ голубя (Kant, 1911а: В 8-9 / A 4-5; Кант, Лосский, Арзакньян и Иткин, 1994а: 36):

Страсть к расширению [знания], увлеченная таким доказательством могущества разума, не признает никаких границ. Рассекая в свободном полете воздух и чувствуя его противодействие, легкий голубь мог бы вообразить, 
что в безвоздушном пространстве ему было бы гораздо удобнее летать. Точно так же Платон покинул чувственно воспринимаемый мир, потому что этот мир ставит узкие рамки рассудку, и отважился пуститься за пределы его на крыльях идей в пустое пространство чистого рассудка. Он не заметил, что своими усилиями он не пролагал дороги, так как не встречал никакого сопротивления, которое служило бы как бы опорой для приложения его сил, дабы сдвинуть рассудок с места. Но такова уж обычно судьба человеческого разума, когда он пускается в спекуляцию...

Именно этот знаменитый пассаж Канта и выступал для многих кантоведов подосновой философской программы цёлльнеровской медали (см.: Vaihinger, 1881: 246-247; Hinske, 1995: 98; Хинске, Ойзерман, 1999: 234).

\section{4. СОВА МИНЕРВЫ И РОЗА НА КРЕСТЕ}

Менее чем за год до неожиданной смерти, в зените славы Георг Вильгельм Фридрих Гегель получил в подарок на свое шестидесятилетие юбилейную медаль (см. илл. 10). Эту медаль на основе наброска моло-
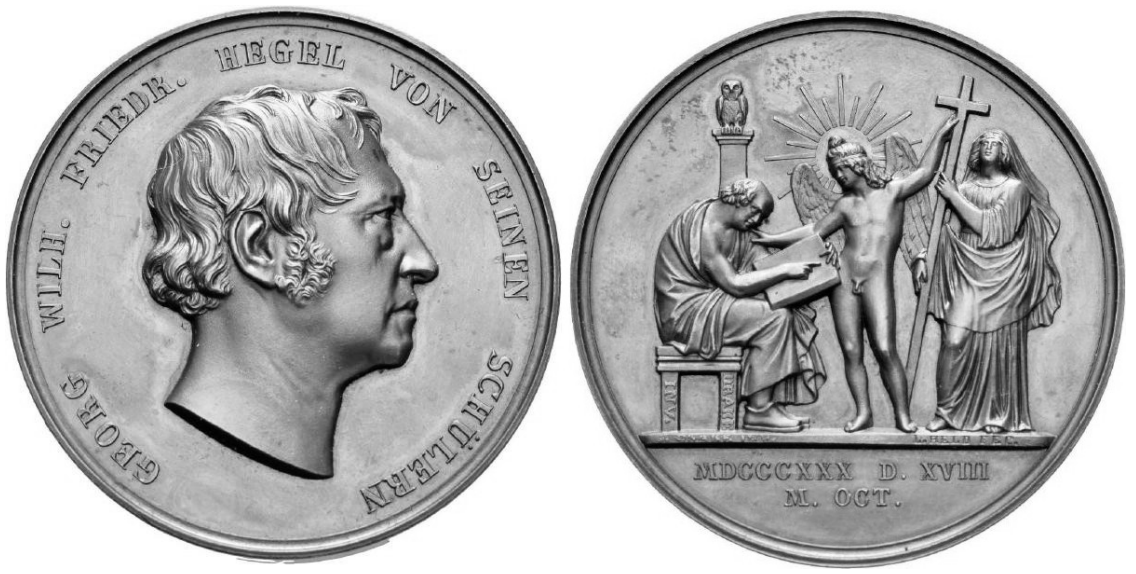

Илл. 10. Юбилейная медаль к шестидесятилетию Г. В. Ф. Гегеля 1830 года.

Чеканка А. Л. Хелда (Laverrenz, 1887: Taf. LIII. № 209; Gulyga, Seidel, 1980: 283).

дого скульптора Иоганна Фридриха Драке изготовил молодой медальер Август Людвиг Хелд. На аверсе наряду с профилем философа имеется надпись - «Георгу Вильг. Фридр. Гегелю от его учеников». На реверсе помимо указания даты-18 октября 1830 года (хотя золотая медаль 
и была вручена Гегелю лишь 3 декабря 1830 года (см.: Zelter, 1834 b: 78 . № 755) - была изображена композиция, смысл которой остается загадочным и по сей день. В отличие от ранее рассмотренных медалей, изображение не сопровождает какая-либо латинская или немецкая надпись. Стандартное описание изображения на реверсе гласит: «Философия и религия, объединенные гением. Аллегорически изображено Драке, изготовлено резчиком печатей Л. Хелдом» (Laverrenz, 1887: 151. № 209).

Попытку философской интерпретации этой медали, которая Гегелю, в отличие от Канта, не оценившего собственную юбилейную медаль, явно понравилась - по крайней мере, известно о том, что копии этой медали он в качестве подарка рассылал своим знакомым (см.: Jaeschke, 2016: 50, 273),- представил в начале хх века известный гегелевед Георг Лассон. В статье под названием «Крест и роза. Попытка интерпретации» (Lasson, 1909) на основе гегелевской юбилейной медали Лассон дал собственное понимание ключевой, с его точки зрения, фразы всей гегелевской философии (Hegel, 1989a: 26-27; Гегель, Столпнер и Левина, 1990: 55; cp. Hegel, 2015: 601):

Познать разум как розу на кресте современности и возрадоваться ей-это разумное понимание есть примирение с действительностью, которое философия дает тем, кто услышал внутренний голос, требовавший постижения в понятиях и сохранения субъективной свободы не в особенном и случайном, а в том, что есть в себе и для себя.

Эту загадочную фразу из «Философии права» Лассон истолковывал, опираясь на столь же загадочный реверс гегелевской юбилейной медали, на котором крест посредине украшен розой. При этом он высказывал серьезную критику за непонимание смысла изображения на медали, гегелевских слов и гегелевской философии в адрес Иоганна Вольфганга Гёте, его друга, композитора Карла Фридриха Цельтера, а также историка философии Куно Фишера (Lasson, 1909: 44-45). При всей проницательности и глубине интерпретации Лассона она страдает одним небольшим недостатком: на медали изображен крест, но роза на ней отсутствует. В отличие от Цельтера и Гёте, получивших от Гегеля копии юбилейной медали и высказывавших свое недоумение на основе увиденного собственными глазами, Лассон медаль не видел, а писал о ней с чьих-то слов, в результате чего и возникло это фактическое недоразумение.

Но что же тогда изображено на реверсе? Стоящая женская фигура с крестом, смотрящая на небо, толковалась и как вера, и как религия, 
и как теология. Сидящая же мужская фигура ученого с книгой трактовалась и как философия, и как наука, и как знание. Если крест явным образом относится к женской фигуре, то колонна, увенчанная совой Минервы, - к сидящей мужской. В отличие от медали Абрамсона на смерть Канта, на гегелевской юбилейной медали сова и Минерва - не два разных персонажа, к тому же совершающих разнонаправленные действия, а персонажи, совпадающие между собой, как это имело место и у самого Гегеля: «...сова Минервы начинает свой полет лишь с наступлением сумерек» (Hegel, 1989b: 28; Гегель, Столпнер и Левина, 1990: 56). Но функция этой не летящей, как на медали Канта, а неподвижно сидящей совы плохо понятна - возможно, сумерки еще не наступили? Правда, чем тогда занята фигура с книгой, если - судя по неподвижной сове- время философии еще не пришло? Находящийся же между крайними фигурами гений, ангелоподобный дух-хранитель в ореоле лучей, выполняет роль посредника, держась одной рукой за крест, а другойза плечо ученого (возможно, помимо плеча касающейся еще и колонны с мудростью).

Именно это изображенное посредничество и вызвало негативные отклики со стороны Гёте. Цельтер, которому Гегель лично принес в подарок два экземпляра медали - один для Гёте,- писал последнему: «Голова хороша и не без сходства; оборотная сторона мне не понравилась. Кто принуждает меня любить крест, хотя я и сам должен его носить?!» (Zelter, 1834а: 88. № 759) Получив медаль уже после смерти Гегеля, Гёте ответил своему другу:

Похвальный профиль медали (Гегеля) во всех смыслах очень удался. [...] Об оборотной стороне я не знаю, что сказать. Мне кажется, она открывает бездну, которую я, однако, при моем приближении к вечной жизни всегда игнорировал (Goethe, 1834a: 194. № 791).

Свое большое неудовольствие реверсом гегелевской медали Гёте выражал Цельтеру и позднее:

Совершенно не ясно, что это должно значить. То, что я умею почитать и украшать крест как человек и как поэт, я доказал в моих стансах; но то, что философ ведет своих учеников к этой смычке окольным путем праоснований и безосновностей сущности и не-сущности, меня не удовлетворяет. Это можно проще достичь и лучше высказать (Goethe, 1834b: 384. № 843).

Стихи, упоминаемые здесь Гёте,- - это его незаконченный фрагмент под названием «Тайны» конца XVIII века, в котором поэт на свой лад, 
отличный от гегелевского, обошелся с темой розы и креста (Goethe, 1828: 179-191; Гёте, Пастернак, 1922).

Гёте сравнил гегелевскую медаль с иной медалью, которая хранилась в его коллекции, придя к следующему выводу (Goethe, 1834b: 384. № 843):

У меня имеется медаль XVII века с портретом высокого римского священника; на оборотной стороне Theologia и Philosophia, две благородные дамы друг напротив друга, и это отношение обдумано настолько прекрасно и чисто, а выражено настолько совершенно удовлетворительно и любезно, что я храню этот образ в тайне, дабы-если мне это суждено будет испытать - достать его достойному.
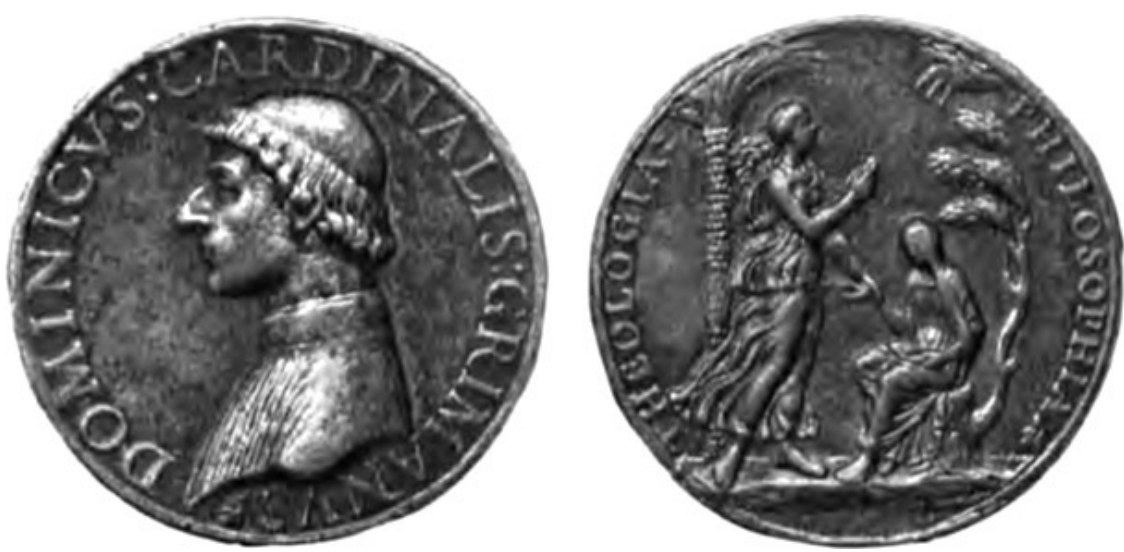

Илл. 11. Медаль кардиналу Доменико Гримани. Аверс: «Dominicvs Cardinalis Grimanvs». Реверс: «Theologia-Philosophia» (Renaissance Medals, 1967: Илл. 236. Б. п. $)^{21}$.

Если ориентироваться на каталог коллекций Гёте, речь идет о медали, посвященной кардиналу Доменико Гримани - правда, вероятно, более раннего времени, нежели XVII век (см. илл. 11) (Goethe's Kunstsammlungen, 1848: 57. № 83):

Theologia-Philosophia. Стоящая под пальмой женская фигура, указующая правой рукой на Солнце и берущая за руку вторую, склоненно сидящую и держащую книгу у лона.

${ }^{21}$ См. описание медали (Renaissance Medals, 1967: 46. № 236). 
С этим сходны и иные описания данной медали: «Теология приподнимает сидящей философии руку и показывает ей на небо» (Denis, 1780: 724), «Theologia-Philosophia. Первая наставляет вторую» (Verzeichniss der Münz- und Medaillen-Sammlung..., 1845: 675. № 13807).

Сравниваемые Гёте медали имеют несомненные сходства: на обеих теология, или религия, изображена в виде стоящей женской фигуры, на обеих то, что можно воспринять в виде философии, изображается сидящей фигурой с книгой, будь то женской или мужской. Но и отличия между ними разительные: на старой медали для некоего единения теологии и философии не требуется никакого посредника, они прекрасно обходятся друг с другом вдвоем. Несмотря на выраженное иерархичное отношение, между теологией и философией царит гармония. Учитывая род занятий Гегеля, можно было бы еще понять, если бы в роли гения-посредника на его юбилейной медали выступала философия, философ или же сам Гегель, однако на ней изображено нечто прямо противоположное.
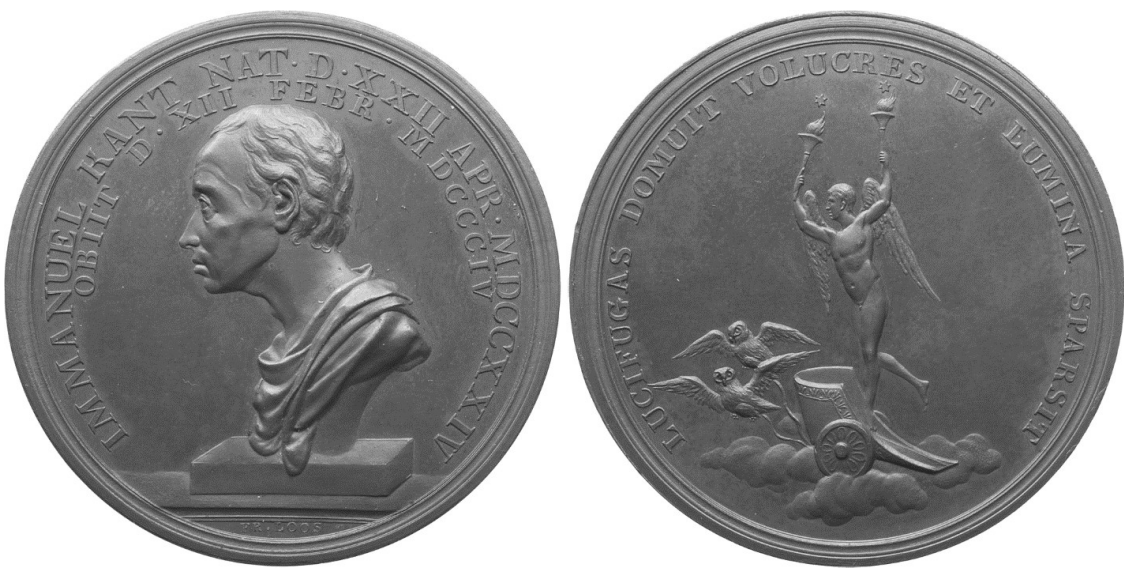

Илл. 12. Медаль на смерть И. Канта 1804 года. Чеканка Ф. В. Лооса (Schubert, 1842: фронтиспис; Immanuel Kant: Erkenntnis..., 2004: 221).

Эта двусмысленность роли гения становится еще более заметной, если сравнить гегелевскую юбилейную медаль с еще одной медалью на смерть Канта, которая также имелась в собрании Гёте и была изготовлена Фридрихом Лоосом на основе кантовского бюста работы Фридриха Хагеманна (аверс) (см. илл. 12). Описание ее реверса выгля- 
дит в разных изданиях следующим образом: «Крылатый гений с двумя высоко поднятыми факелами на колеснице, ведомой совами» (Goethe's Kunstsammlungen, 1848: 185. № 1486) или

Кант стоит на запряженной двумя совами колеснице, гений философии, и держит в руках два факела, над которыми как знак того, что здесь светит истинная мудрость, сияют две звезды (Verzeichniß sämmtlicher Denk- und Gelegenheitsmünzen..., 1842: $33^{-} 34$. № 28).

Кантовский биограф $\Phi$. В. Шуберт добавляет к этому еще тот штрих, что колесница движется по небу сквозь облака (Schubert, 1842: 209), исследователь-любитель $\Phi$. Лёв - что это не просто гений, а гений просветляющей победоносной философии, а факелы подняты вверх триумфальным образом (Loew, 1828: 118), а нумизмат K. Лаверренц называет триумфальной также и саму колесницу гения (Laverrenz, 1887: 55. № 111) 22. Изображение сопровождается многозначительной латинской надписью «Lucifugas domuit volucres et lumina sparsit».

Смысл изображения на реверсе в комбинации с латинским изречением стал предметом полемики уже в год смерти Канта и чеканки монетыв 1804 году. В сообщении «Памятная медаль философу Канту» утверждалось (Denkmünze auf den Philosophen Kant, 1804b: 768):

На оборотной стороне видят гения освещающей победоносной философии. Он стоит на колеснице, в которую запряжены две совы. Сова всегда была пугающейся света птицей, которая и в древних Афинах лишь благодаря случайной особенности той местности, в которой было установлено любимое местопребывание Афины Паллады, оказалась в обществе богини мудрости. Минерва привлекла этих птиц на свою службу, но она не благоприятствовала им и не любила их. Она запрягла их в свою повозку. Это представление является античным, можно обнаружить Минерву, передвигающуюся таким образом, на древних монетах и геммах. Этот же гений, словно посланный Минервой, подобно ей, принуждающей этих одиноких птиц ночи к службе, парит в воздухе, триумфально вознося в своих руках вверх два факела. В качестве знака, что здесь светит истинная мудрость, над каждым сияет звезда. Надпись доказывает власть и благотворность подлинной философии, которая столь действенно была восстановлена нашим Кантом. Lucifugas domuit volucres et lumina sparsit. По-немецки: Он усмирил боящихся света птич и источил лучистый свет. Идея, а также надпись в соответствии с указанием славного исследователя древности, г-на Бёттигера из Веймара....

${ }^{22}$ Наиболее обстоятельно, объединяя в себе почти все черты вышеуказанных описаний, еще в год смерти Канта в анонимной заметке (Denkmünze auf den Philosophen Kant, 1804а: Б. п.). 
Данное сообщение сопровождалось анонимно напечатанным двустишием пародийного характера, автором которого был как раз Гёте: «Смотри-ка! Укрощенное племя пугающихся света ворчащих чудаков / Само провезет тебя, о Кант, сквозь облака» (Intelligenzblatt der Jenaischen..., 1804: 767-768).

Реакция на эту публикацию вскоре появилась в журнале «Прямодушный» под редакцией Августа фон Коцебу: автор «Йенской литературной газеты» потешным образом совершенно не заметил того, что знаменитый археолог Карл Август Бёттигер ${ }^{23}$ выразил в этой медали свое отношение к кантианцам (Nicht-politische Zeitung, 1804: 168. 28. August):

...он не заметил, что эта медаль, возвеличивая Канта, оказывается самой горькой сатирой на его глупых идолопоклонников и последователей. Колесница несущего свет движется существами, которые совершенно не способны наслаждаться его светом. Может ли нечто быть более отчетливым?ㄴ

В самом ли деле таким уничижительным образом в виде сов на медали показаны несчастные кантианцы, которым кантовская философия-не в коня корм, или же это все же совы, пребывающие на службе мудрости, ясно то, что на обеих медалях на смерть Канта совы деятельны: либо сова рвется в недостижимую высь, либо же совы и вовсе, подобно коням, запряжены в колесницу, которую и везут по небу. Сова же на гегелевской медали выполняет роль памятника-истукана ${ }^{25}$, в лучшем случае намекающего на род занятий сидящего рядом с ней. У алетофилов Минерва обходилась без совы, у Абрамсона она придерживала сову, у Лооса Кант, как посланник Минервы, ехал на совах. На гегелевской же медали сова осталась, а Минерва пропала. И если роковым для гегелевской совы оказывалось светлое время суток, то и здесь имеется разительный контраст с кантовской памятной медалью, на которой кенигсбергский философ оказался в состоянии заставить сов летать и трудиться даже

23Примечательно, что на смерть самого Бёттигера А. Ф. Кёнигом в 1835 году была отчеканена медаль, на реверсе которой было изображение как раз совы, держащей в своих лапах лавровую ветвь и свиток, сопровождаемое латинской надписью о радости покойного ученого по поводу учеников и источников античной культуры. См. изображение и описание (Gelehrtenbilder, 2020: 44-45).

${ }^{24}$ Вариант перевода латинского изречения на немецкий здесь иной: «Он усмирил пугающихся света птиц и применил ясность».

${ }^{25}$ Хотя сова на постаменте встречалась на медалях и раньше-в частности на медали на смерть Иоганна Георга Зульцера работы все того же Абрамсона ок. 1779 года,- - но на ней сова все же живая, как и на медали Бёттигера, и держит в своих лапах лиру как символ изящных наук, перед которыми Зульцер имел особые заслуги. 
и при ярком свете. Но еще важнее иное: духом-гением на медали Лооса оказывается сам Кант, и освещает всю округу просветительским светом собственной философии сам кенигсбергский философ. На гегелевской же медали гением может быть кто и что угодно, но только не философия, символизируемая сидящей фигурой и / или колонной с совой, и не Гегель. Возможно, сложности изображения связаны с отсутствием какого-либо изречения, а также с тем, что гегелевская медаль - это, похоже, продукт художников, а не философов и художников, как это было в случае медали алетофилов или кантовских медалей (Готтшед, Мендельсон, Герц, Цёлльнер, Бёттигер...).

Если на старой медали с кардиналом теология и философия пребывают в непосредственном телесном контакте друг с другом, а теология любовно пытается приподнять и саму фигуру философии, и ее взгляд от земного к горнему, то на гегелевской медали теология / религия и философия если вообще и взаимодействуют, то лишь вдвойне опосредованно: философия уткнулась взглядом в книгу и не видит ничего иного, теология / религия же смотрит в небо и не видит возле себя никакой философии. Непонятного свойства гений пытается их как-то соединить, но даже и здесь это не посредничество между теологией / религией и философией, а посредничество гения между философией и крестом, который держит в руках теология / религия. В таком случае именно крест, к которому гений призывает философию, т. е. как раз то, что вызвало резкую отповедь со стороны Цельтера, и оказывается главным посланием гегелевской медали.

Но если Гёте, несмотря на всю свою критику, все же вспоминал в связи с гегелевской медалью собственные стихи о кресте и розе, а Лассон, пусть и не видя самой медали, тоже пытался связать ее с образом розы на кресте в произведениях Гегеля, то, может быть, она и вправду способна прояснить эту гегелевскую позицию? Мысль, ярко выраженная в предисловии к «Философии права», возможно, и является финальной точкой в развитии этого взгляда Гегеля, но вряд ли она объемлет в себе все предшествующие и отличающиеся от нее стадии. В статье «Кто мыслит абстрактно?» (Hegel, 1989с: 578-579; Гегель, Ильенков, 1970: 392) и в лекциях по философии религии (Hegel, 1990: 272; Гегель, Левина, 1975: 428) можно обнаружить розу на кресте с иными акцентами. Мне не известно, знал ли Гегель о фрагменте Гёте «Тайны», но накануне и вскоре после трехсотлетнего юбилея Реформации в 1817 году были свежи воспоминания о Мартине Лютере и его знаменитом гербе с черным 
крестом, красным сердцем и белой розой, печать с которыми являлась, по утверждению самого Лютера, знаком его теологии (см. илл. 13) ${ }^{26}$. Однако в сравнении с медалью алетофилов и двумя кантовскими медалями Абрамсона, которые и в самом деле позволяют понять важные черты немецкого Просвещения или восприятия кантовской философии,

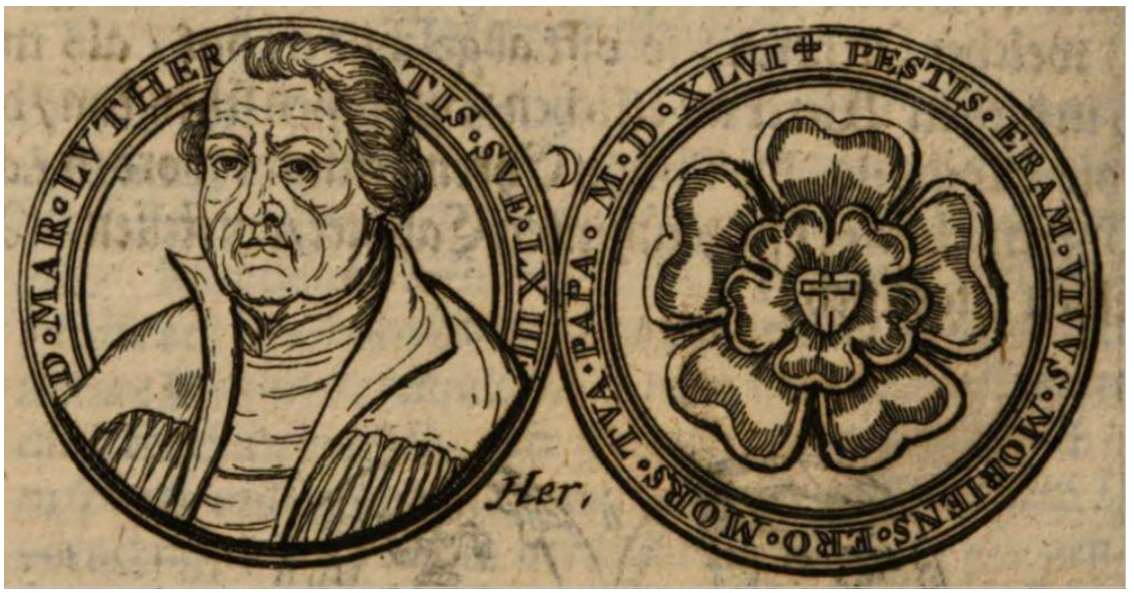

Илл. 13. Медаль на смерть М. Лютера из собрания К. Г. Хереуса (Juncker, 1706: 552). На реверсе-герб Лютера с крестом, сердцем и розой с надписью «Pestis eram vivis moriens ero mors tva papa MDXLVI ${ }^{27}$.

гегелевская юбилейная медаль, напротив, скорее свидетельствует о мнимых надеждах с ее помощью прояснить одну из ключевых фраз самого Гегеля - для проникновения в ее глубинный смысл гораздо уместнее обращаться к сочинениям Лютера, Гёте, иным (наряду с «Философией права») работам самого Гегеля ${ }^{28}$, что и предпринимают проницательные исследователи ${ }^{29}$. Медали же и прочие визуальные средства, увы, вряд ли смогут в этом помочь.

${ }^{26}$ См. лютеровское объяснение этого изображение (Luther, 1934: 445. № 1628).

27 Эпитафия Лютера: «Чумой я был при жизни - умирая, я стал твоей смертью, папа».

${ }^{28}$ Наряду с уже упомянутыми выше сочинениями Гегеля интерес представляет также раннее сочинение (Гегель, Иваненко, 2016: 177-179; Гегель, Иваненко, 2017: 162-163; Hegel, 1989a: $39^{-1} 393,43^{2-433) .}$

${ }^{29}$ См. в этой связи, в первую очередь, работу Карла Лёвита (Лёвит, Лощевский, 2002: 108-127). Из более поздних работ см. (Plathow, 2014: 107-122). 


\section{ЛИTEPATУРA}

«Hexalogus Alethophilorum», или Шесть законов Общества любителей истины / пер. с нем. К. А. Волковой // Кантовский сборник. - 2011. - Т. 37, № 3. - C. 91 .

Бэкон Ф. О мудрости древних / пер. с лат. Н. А. Федорова // Сочинения. В 2 т. Т. 2 / под ред. А. Л. Субботина. - М. : Мысль, 1972. - С. 223-296.

Гегель Г. В. Ф. Кто мыслит абстрактно? / пер. с нем. Э. В. Ильенкова // Работы разных лет. В 2 т. Т. 1 / под ред. А.В. Гулыги. - М. : Мысль, 1970. - C. $387^{-} 394$.

Гегель Г. В.Ф. Философия религии. В 2 т. Т. 1 / под ред. А. В. Гулыги ; пер. с нем. М. И. Левиной. - М. : Мысль, 1975.

Гегель Г. В.Ф. Философия права / пер. с нем. Б. Г. Столпнер, М. И. Левиной. - М. : Мысль, 1990.

Гегель Г. В.Ф. Вера и знание или рефлексивная философия субъективности в полноте своих форм как философия Канта, Якоби и Фихте / пер. с нем. А.А. Иваненко // ESSE : Философские и теологические исследования. 2016. - T. 1, № 2. - С. $136-182$.

Гегель Г. В.Ф. Вера и знание или рефлексивная философия субъективности в полноте своих форм как философия Канта, Якоби и Фихте / пер. с нем. А. А. Иваненко // ESSE : Философские и теологические исследования. 2017. - T. 2, № 1. - C. 137-164.

Гёте И. В. Тайны / пер. с нем. Б. Л. Пастернака. - М. : Современник, 1922.

Кант И. Критика чистого разума / пер. с нем. Ц.Г. Лосского Н. О. and Арзаканьяна, М. И. Иткина. - М. : Мысль, 1994а.

Кант И. Ответ на вопрос: Что такое просвещение? / пер. с нем. Ц. Г. Арзаканьяна // Сочинения на русском и немецком языках. В 5 т. Т. 1 / под ред. Н. В. Мотрошиловой, Б. Тушлинга. - М. : Ками, 1994 b. - С. 125-147.

Кант И. Пролегомены ко всякой будущей метафизике, которая может появиться как наука / пер. с нем. В. С. Соловьева // Собрание сочинений. В 8 т. Т. 4 / под ред. А. В. Гулыги. - М. : ЧОРО, 1994с. - С. 5-125.

Кант И. Критика способности суждения / пер. с нем. Н. В. Мотрошиловой, Т.Б. Длугач // Сочинения на русском и немецком языках. В 5 т. Т. 4 / под ред. Н. В. Мотрошиловой, Б. Тушлинга. - М. : Наука, 2001. - С. 69-833. Квинт Гораций Флакк / пер. с лат. Н. С. Гинцбурга // Собрание сочинений / под ред. С. В. Чистобаева. - СПб. : Биографический институт Студия биографика, 1993. - С. 289-342.

Лёвит $K$. От Гегеля к Ницше. Революционный перелом в мышлении хіх века. Маркс и Кьеркегор / под ред. М. Ермаковой, Г. Шапошниковой ; пер. с нем. К. В. Лощевского. - М. : Владимир Даль, 2002.

Мендельсон М. Что значит просвещать? / пер. с нем. К. А. Волковой // Кантовский сборник. - 2011. - Т. 37, № 3. - С. $74^{-7} 7$. 
Север Г. М. / Horatius. - 2008-2016. - URL: https://www.horatius.ru/index.xp s?3.902 (дата обр. 18 марта 2021).

Хинске $H$. «Критика чистого разума» и сфера свободы для веры. K вопросу о восприятии Канта ранним йенским кантианством. Различные восприятия «Критики чистого разума» в 1785 году / пер. Т.И. Ойзермана // Разум и экзистенция. Анализ научных и вненаучных форм мышления / под ред. И. Т. Касавина, В. Н. Поруса. - СПб. : РХГИ, 1999. - С. 231-244.

Шеллинг Ф. В. Й. Иммануил Кант / пер. с нем. М. И. Левиной, А. В. Михайлова // Сочинения. В 2 т. Т. 2 / под ред. А. В. Гулыги. - М. : Мысль, 1989. - С. 27-33. Шиллер Ф. Письма об эстетическом воспитании человека / пер. с нем. Э.Л. Радлова // Собрание сочинений. В 7 т. Т. 6 / под ред. Н.Н. Вильмонта, Р. М. Самарина. - М. : Государственное издательство художественной литературы, 1957. - С. 251-358.

Шульи И. Разъясняющее изложение «Критики чистого разума»: Руководство для чтения / пер. с нем. Б. А. Фохта. - М. : УРСС, 2010.

300 Jahre Universität Halle 1694-1994. Schätze aus den Sammlungen und Kabinetten Halle / hrsg. von R.-T. Speler. - Halle : Ed. Stekofoto, 1994.

Berichte der allgemeinen Buchhandlung der Gelehrten vom Jahr 1783/ hrsg. von C. C. Reiche. - Leipzig : Buchhandlung, 1783 .

Berliner Blätter für Münz-, Siegel- und Wappenkunde. Bd. 5 / hrsg. von W. Weber. - Berlin : W. Weber, 1870.

Borowski L. E. Darstellung des Lebens und Charakters Immanuel Kant's // Immanuel Kant. Sein Leben in Darstellungen von Zeitgenossen. Die Biographien von L. E. Borowski, R. B. Jachmann und E. A. Ch. Wasianski / hrsg. von F. Gross, R. Malter. - Darmstadt : Wissenschaftliche Buchhandlung, 1993. - S. 1-102.

Breitinger J. J. Artis cogitandi principia ad mentem recentiorum philosophorum compendio exhibita, atque in usum privatae institutionis concinnata. - Tiguri : Orell, 1736 .

Brucker J. Bilder-Sal heutiges Tages lebender und durch Gelahrtheit berühmter Schrift-Steller, in welchem derselbigen nach wahren Original-malereyen entworfene Bildnisse in schwarzer Kunst, in natürlicher Aehnlichkeit vorgestellet, und ihre Lebens-umstände, Verdienste um die Wissenschaften und Schriften aus glaubwürdigen Nachrichten erzählet werden. Bd. 7. - Augsburg : Haid, 1748.

Denis M. Die Merkwürdigkeiten der k. k. garellischen öffentl. Bibliothek am Theresiano. Wien : Bernhardi, 1780 .

Denkmünze auf den Philosophen Kant // Dresdner Anzeigen. - 1804a. - Nr. 45. Denkmünze auf den Philosophen Kant // Intelligenzblatt der Jenaischen Allgemeinen Literatur-Zeitung. - 1804b. - Nr. 93. - S. 768.

Dietzsch S. Immanuel Kant im Europa der Aufklärung // Kant der Europäer. Europäer über Kant / hrsg. von S. Dietzsch, L. Grimoni, D. Kozlowski. - Husum : Husum Druck- und Verlagsgesellschaft, 2010. - S. 32-48. 
Engelmann W. Daniel Chodowieck's sämmtliche Kupferstiche beschrieben, mit historischen, literarischen und bibliographischen Nachweisungen, der Lebensbeschreibung des Künstlers und Registern versehen. - Leipzig : Engelmann, 1857.

Essers V. Kant-Bildnisse // Immanuel Kant. Leben - Umwelt-Werk. Ausstellung des Geheimen Staatsarchivs Preußischer Kulturbesitz aus Beständen der Stiftung preußischer Kulturbesitz, der Bayerischen Staatsbibliothek, München, des Hauses Königsberg in Duisburg und anderer Leihgeber zur 250. Wiederkehr von Kants Geburtstag am 22. April 1974/ hrsg. von F. Benninghoven. - Berlin : Friedrich Benninghoven, 1974. - S. 39-63.

Friedländer M. Geschichte der Münze auf Kant // Neue Berlinische Monatsschrift / hrsg. von J. E. Biester. - 1805. - Jg. 1. - S. 398-400.

[Fromm E.] Noch einmal die Kantmedaille mit dem schiefen Turm von Pisa // Kant-Studien. - 1898. - Jg. 2. - S. 376-377.

Gelehrtenbilder. Altertumswissenschaftler auf Medaillen des 19. Jahrhunderts. Begleitband zur online-Ausstellung im Digitalen Münzkabinett des Instituts für Klassische Archäologie der Universität Tübingen / hrsg. von S. Krmnicek, M. Gaidys. - Tübingen : Universität Tübingen, 2020.

Goethe J.W. Die Geheimnisse // Goethe's Werke. Vollständige Ausgabe letzter Hand. Bd. 13. - Stuttgart : Gottai'sche Buchhandlung, 1828. - S. 179-191.

Goethe J. W. Brief an C.F. Zelter vom 1. Juni $1831 / /$ Briefwechsel zwischen Goethe und Zelter in den Jahren 1796 bis 1832. Bd. 6 / hrsg. von F. W. Riemer. - Berlin : Duncker und Humblot, 1834a. - S. 193-196.

Goethe J. W. Brief an C.F. Zelter vom 27. Januar $183^{2} / /$ Briefwechsel zwischen Goethe und Zelter in den Jahren 1796 bis $183^{2}$. Bd. $6 /$ hrsg. von F. W. Riemer. Berlin : Duncker und Humblot, 1834 b. - S. $3^{82-} 3^{85}$.

Goethe's Kunstsammlungen. Tl. 2 : Geschnittene Steine, Bronzen, Medaillen, Münzen; Arbeiten in Marmor, Elfenbein und Holz; antike Vasen und Terracotten, Gypsabgüsse, Majolica u. A. / hrsg. von C. Schuchardt. - Jena : Friedrich Frommann, 1848.

Götten G. W. Das Jetzt-lebende Gelehrte Europa, Oder Nachrichten Von den vornehmsten Lebens-Umständen und Schrifften, jetzt lebender Europäischer Gelehrten. Tl. II. - Braunschweig : Ludolph Schröder, 1736.

Gottsched J. C. Historische Lobschrift des weiland hoch- und wohlgebohrnen Herrn Christians, Herrn des H. R. R. Freyherrn von Wolf. - Halle : Rengerische Buchhandlung, 1755 .

Gottsched J. C. Das Andenken des vor 100 Jahren in Leipzig gebohrnen Freyherr Gottfried Wilhelms von Leibnitz // Ausgewählte Werke. Bd. 1 / hrsg. von J. Birke. - Berlin : De Gruyter, 1968. - S. 188-203.

Gottsched L. A. V. Brief an E. Chr. von Manteuffel vom 5. Januar 1740 // Auftrage der Sächsischen Akademie der Wissenschaften zu Leipzig hrsg. von D. Döring, M. Rudersdorf. Bd. 6 / hrsg. von M. Rudersdorf. - Berlin : De Gruyter, 2012. - S. 285-289. 
Grundlegung zur Metaphysik der Sitten von Immanuel Kant, 8 Bog. 8 // Allgemeine Literatur-Zeitung / hrsg. von J. F. Hartknoch. - 1785. - Jg. 2, Nr. 80. - S. 21-23. Gulyga A. V. Georg Wilhelm Friedrich Hegel / übers. von W. Seidel. - Leipzig : Reclam, 1980.

Hamann J. G. Brief an Johann Georg Scheffner vom 15. März 1784 // Briefwechsel. Bd. 5 / hrsg. von W. Ziesemer, A. Henkel. - Wiesbaden : Insel Verlag, 1965. - S. 134 .

Hasse J. G. Letzte Aeußerungen Kant's von einem seiner Tischgenossen. - Königsberg : Nikolovius, 1804.

Hegel G. W. F. Glauben und Wissen oder Reflexionsphilosophie der Subjektivität in der Vollständigkeit ihrer Formen als Kantische, Jacobische und Fichtesche Philosophie // Werke. In 20 Bde. Bd. 2 / hrsg. von E. Moldenhauer, K. M. Michel. - Frankfurt am Main : Suhrkamp, 1989a. - S. 287-433. - auf der Grundlage der Werke von 1832-1845.

Hegel G. W. F. Grundlinien der Philosophie des Rechts oder Naturrecht und Staatswissenschaft im Grundrisse // Werke. In 20 Bde. Bd. 7 / hrsg. von E. Moldenhauer, K. M. Michel. - Frankfurt am Main : Suhrkamp, 1989b. - S. 11-514. - auf der Grundlage der Werke von 1832-1845.

Hegel G. W. F. Wer denkt abstrakt? // Werke. In 20 Bde. Bd. $2 /$ hrsg. von E. Moldenhauer, K. M. Michel. - Frankfurt am Main : Suhrkamp, 1989c. - S. 575581. - auf der Grundlage der Werke von 1832-1845.

Hegel G. W. F. Vorlesungen über die Philosophie der Religion I // Werke. In 20 Bde. Bd. 16 / hrsg. von E. Moldenhauer, K. M. Michel. - Frankfurt am Main : Suhrkamp, 1990. - S. 9-442. - auf der Grundlage der Werke von 1832-1845.

Hegel G. W.F. Vorlesungen über die Philosophie des Rechts. Nachschriften zu den Kollegien der Jahre 1821/22 // Gesammelte Werke. Bd. 26.2. - Hamburg : Meiner, 2015. - S. 593-766.

Hinske N. Die Kritik der reinen Vernunft und der Freiraum des Glaubens. Zur Kantrezeption des Jenaer Frühkantianismus // Aufklärung und Skepsis. Studien zur Philosophie und Geistesgeschichte des 17. und 18. Jahrhunderts Günter Gawlick zum 65. Geburtstag / hrsg. von L. Kreimendahl. - Stuttgart-Bad Cannstatt : Frommann-Holzboog, 1995. - S. 231-243.

Immanuel Kant : Erkenntnis - Freiheit - Frieden. Katalog zur Ausstellung anlässlich des 200. Todestages am 12. Februar 2004, Museum Stadt Königsberg der Stadtgemeinschaft Königsberg (Pr.) im Kultur- und Stadthistorischen Museum Duisburg / hrsg. von L. Grimoni, M. Will. - Husum : Husum Verlag, 2004.

Immanuel Kant und seine Geistesthat // Psyche. Zeitschrift für die Kenntnis des menschlichen Seelen- und Geisteslebense. Bd. 1 / hrsg. von L. Noack. - Herausgeber : FB\&C Ltd., 1858. - S. 1-45.

Intelligenzblatt der Jenaischen Allgemeinen Literatur-Zeitung. — 1804. - Nr. 93. Jaeschke W. Hegel-Handbuch. Leben - Werk - Schule. - Stuttgart : J. B. Metzler, 2016. 
Johann Peter Nicerons Nachrichten von den Begebenheiten und Schriften berümter Gelehrten mit einigen Zusätzen / hrsg. von F. E. Rambach. - Halle : Verlag und Druck Christoph Peter Franckens, 1760.

Juncker C. Das Guldene und Silberne Ehren-Gedächtniß Des Theuren GottesLehrers D. Martini Lvtheri... - Frankfurt : Johann Andreä Endters sel. Sohn und Erben, 1706.

Kant I. Kritik der reinen Vernunft // Kant's Gesammelte Schriften. Bd. 3 / hrsg. von K. P. A. der Wissenschaften. - Berlin : Georg Reimer, 1911a. - S. 1-552.

Kant I. Prolegomena zu einer jeden künftigen Metaphysik, die als Wissenschaft wird auftreten können // Kant's Gesammelte Schriften. Bd. 4 / hrsg. von K. P. A. der Wissenschaften. - Berlin : Walter de Gruyter, 1911b. - S. 253-384.

Kant I. Kritik der Urteilskraft // Kant's Gesammelte Schriften. Bd. 5 / hrsg. von K. P. A. der Wissenschaften. - Berlin : Georg Reimer, 1913. - S. 165-486.

Kant I. Bestimmung über die Verschenkung der goldenen Kant-Medaille // Kant's Gesammelte Schriften. Bd. 12 / hrsg. von K. P. A. der Wissenschaften. - Berlin : Walter de Gruyter, 1922a. - S. 392.

Kant I. Brief an Chr. G. Schütz vom 13. September 1785 // Kant's Gesammelte Schriften. Bd. 10 / hrsg. von K.P. A. der Wissenschaften. - Berlin : Walter de Gruyter, 1922b. - S. 406-407.

Kant I. Brief an J. Schultz vom 4. März 1784// Kant's Gesammelte Schriften. Bd. $10 /$ hrsg. von K. P. A. der Wissenschaften. - Berlin : Walter de Gruyter, 1922c. - S. $368-369$.

Kant I. Brief an M. Herz vom 11. Mai 1781// Kant's Gesammelte Schriften. Bd. $10 /$ hrsg. von K. P. A. der Wissenschaften. - Berlin : Walter de Gruyter, 1922d. - S. 268-270.

Kant I. Brief an M. Mendelssohn vom 16. August 1783// Kant's Gesammelte Schriften. Bd. $10 /$ hrsg. von K.P. A. der Wissenschaften. - Berlin : Walter de Gruyter, 1922e. - S. 344-347.

Kant I. Ergänzungsstück zum Testament // Kant's Gesammelte Schriften. Bd. 12 / hrsg. von K. P. A. der Wissenschaften. - Berlin : Walter de Gruyter, 1922f. S. 391.

Kant I. Kant's Gesammelte Schriften. Bd. 13 / hrsg. von K. P. A. der Wissenschaften. - Berlin : Walter de Gruyter, 1922g.

Kant I. Beantwortung der Frage : Was ist Aufklärung? // Kant's Gesammelte Schriften. Bd. 8 / hrsg. von K. P. A. der Wissenschaften. - Berlin : Walter de Gruyter, 1923. - S. 35-42.

Kantiana. Beiträge zu Immanuel Kants Leben und Schriften / hrsg. von R. Reicke. Theile : Königsberg, 1860.

Köhler J. D. Wöchentliche historische Münz-Belustigung, Darinnen allerhand merckwürdige und rare Thaler, Ducaten, Schaustücken, andere sonderbahre Gold- und Silber-Münzen. Bd. 12. - Nürnberg : Weigel, 1740. 
Köhler J. D. Wöchentliche historische Münz-Belustigung, Darinnen allerhand merckwürdige und rare Thaler, Ducaten, Schaustücken, andere sonderbahre Gold- und Silber-Münzen. Bd. 13. - Nürnberg : Weigel, 1741.

Königl. grosbr. genealogischer Kalender auf das Jahr 1780. - Lauenburg : Berenberg, 1780 .

Kundmann J. C. Die hohen und niedern Schulen Teutschlandes, insonderheit des Hertzogthums Schlesiens, mit ihren Bücher-Vorräthen, in Müntzen, Denen ein Anhang alter rarer goldener Müntzen, so bey Grundgrabung des Hospital-Gebäudes zu Jauer anno 1726 gefunden worden, beygefüget. - Breslau : Johann Jacob Korn, 1741 .

Künste // Intelligenzblatt der allgemeinen Literatur-Zeitung. - 1804. - Nr. 6o. S. $482-483$.

Lasson G. Kreuz und Rose. Ein Interpretationsversuch // Beiträge zur HegelForschung. - Berlin : Trowitzsch, 1909. - S. 43-70.

Laverrenz C. Die Medaillen und Gedächtniszeichen der deutschen Hochschulen. Ein Beitrag zur Geschichte der Universitäten Deutschlands. Bd. 2. - Berlin : Laverrenz, 1887 .

Leben der ausgezeichnetsten Maler, Bildhauer und Baumeister von Cimabue bis zum Jahre 1567, beschrieben von Giorgio Vasari, aus dem Italienischen. Bd. 1 / hrsg. von L. Schorn. - Stuttgart : B. c., $183^{2}$.

Lesser F.-C. Besondere Müntzen Welche So wohl auf Gelehrte Gesellschafften nemlich Universitäten, Societäten, Seminaria und Gymnasia Als auch Auf gelehrte Leute nemlich Theologos, Jure- Consultos, Medicos und Philosophos, Sonderlich auf den theuren D. Martin Luthern, nach Junchers herausgegebenen güldenen und silbernen Ehren-Gedächtniß Desselben gepräget worden. Mit Kupfern. Frankfurt : Blochberger, 1739 .

Lichtenberg G. C. Nicolaus Copernicus // Vermischte Schriften. - Göttingen : Dieterich, 1844. - S. 151-244. - Neue vermehrte, von dessen Söhne veranstaltete Original-Ausgabe.

Lichtenberg G. C. Brief an I. Kant vom 30. Oktober $1791 / /$ Kant's Gesammelte Schriften. Bd. 11 / I. Kant ; hrsg. von K. P. A. der Wissenschaften. - Berlin : Walter de Gruyter, 1922. - S. 302-303.

Lichtenberg G. C. Sudelbücher // Schriften und Briefe. Bd. 1 / hrsg. von W. Promies. - Frankfurt am Main : Zweitausendeins, 1994. - S. 7-950.

Lichtenberg G. C. Gesammelte Schriften. Historisch-kritische und kommentierte Ausgabe. Bd. 3. T. 1. Vorlesungen zur Naturlehre : Notizen und Materialien zur Experimentalphysik / hrsg. von H. Zehe, A. Krayer, W. Hinrichs. - Göttingen : Wallstein Verlag, 2007.

Loew $F$. Ueber das Münzwesen der alten und der neuen Zeit mit angehängten Reductions-Tabellen der dermalen bei den verschiedenen Völkern aller Welttheile geltenden Münzsorten. Aus Original-Quellen bearbeitet. - Regensburg : Loew, 1828. 
Ludovici C. G. Ausführlicher Entwurf einer vollständigen Historie der Wolffischen Philosophie. In 3 Bde. Bd. 1. - Leipzig : Löwe, 1738.

Luther M. Brief an L. Spengler vom 8. Juli 1530 // Dr. Martin Luthers Werke. Kritische Gesamtausgabe. Briefwechsel. Bd. 5. - Weimar : Hermann Böhlaus Nachfolger, 1934. - S. 445.

Mendelssohn M. Morgenstunden oder Vorlesungen über das Daseyn Gottes. Bd. 1. Berlin : Voss, 1786.

Mendelssohn M. Brief an I. Kant vom 10. April 1783 // Kant's Gesammelte Schriften. Bd. 10 / I. Kant ; hrsg. von K. P. A. der Wissenschaften. - Berlin : Walter de Gruyter, 1922. - S. 307-308.

Mendelssohn M. Brief an M. Herz vom 18. November 1783// Gesammelte Schriften. Jubiläumsausgabe. Bd. 13 / hrsg. von I. u. a. Elbogen. - Stuttgart-Bad Cannstatt : Frommann-Holzboog, 1977. - S. 160-161.

Meusel J. G. Teutsches Künstlerlexikon oder Verzeichnis der jetztlebenden teutschen Künstler. Nebst einem Verzeichniss sehenswürdiger Bibliotheken, KunstMünz- und Naturalienkabinete in Teutschland und in der Schweiz. Bd. 1. Lemgo : Meyer, 1808.

Miscellen // Der Freimüthige oder Ernst und Scherz / hrsg. von A. von Kotzebue. 1804. - Nr. 61/62. - S. 244.

[Mortzfeld J. Chr.] Fragmente aus Kants Leben. Ein biographischer Versuch. Königsberg : Hering und Haberland, 1802.

Nachricht von der zu Berlin auf der Gesellschaft der Alethophilorum oder Liebhaber der Wahrheit geschlagenen Müntze. - Berlin : Haude, 1740.

Nicht-politische Zeitung No. 30 // Der Freimüthige oder Ernst und Scherz / hrsg. von A. von Kotzebue. - 1804. - Nr. 172. - S. 168.

Nilsson H. Erik Wallers samling av medicinhistoriska medaljer. - Uppsala : Uppsala Universitet, 2013 .

Plathow M. Vor Gott in der Welt. Luthers neues Wirklichkeitsverständnis. - Berlin : Lit Verlag, 2014.

Renaissance Medals from the Samuel H. Kress Collection at the National Gallery of Art Based on the Catalogue of Renaissance Medals in the Gustave Dreyfus Collection / ed. by G. Pollard. - London : Phaidon Press, 1967 .

Rizzini P. Illustrazione dei civici musei di Brescia. - Brescia : F. Apollonio, 1892. Rosenkranz K. Geschichte der Kant'schen Philosophie // Immanuel Kant's Sämmtliche Werke. Bd. 12 / hrsg. von K. Rosenkranz, F. W. Schubert. - Leipzig : Voss, 1840. - S. 1-498.

Sammlung auserlesener Sendschreiben, welche im 1739ten und im Anfange des 1740ten Jahres an Hrn. Johann Christoph Gottscheden, von vielen gelehrten Männern eingelaufen sind. Bd. 5. Sendschreiben an Gottscheden / hrsg. von J. C. Gottsched. - Dresdner Digitalisierungszentrum, 1739-1740.

Schelling F. von. Immanuel Kant // Sämmtliche Werke. Bd. 6. - Stuttgart, Augsburg : Cotta, 1860. - S. 1-10. 
Schiller F. Ueber die ästhetische Erziehung des Menschen in einer Reyhe von Briefen // Die Horen. Bd. 1 / hrsg. von F. Schiller. - Tübingen : J. G. Cottaische Buchhandlung, 1795. - S. $7^{-48}$.

Schneiders W. Hoffnung auf Vernunft. Aufklärungsphilosophie in Deutschland. Hamburg : Meiner, 1990.

Scholz O. „Erscheinet doch endlich, ihr güldenen Zeiten! / Da Weisheit und Tugend die Menschen regiert."- Johann Christoph Gottsched als Aufklärer // Johann Christoph Gottsched (1700-1766) : Philosophie, Poetik und Wissenschaft / hrsg. von E. Achermann. - Berlin : Akademie Verlag, 2014. - S. 27-38.

Schröpfer H. Kants Weg in die Öffentlichkeit : Christian Gottfried Schütz als Wegbereiter der kritischen Philosophie. - Stuttgart-Bad Cannstatt : Frommann-Holzboog, 2003.

Schubert F. W. Immanuel Kant's Biographie // Immanuel Kant's Sämmtliche Werke. Bd. 11 / hrsg. von K. Rosenkranz, F. W. Schubert. - Leipzig : Voss, 1842. - S. 1-220.

Schultz [Schulze] J. Erläuterungen über des Herrn Professor Kant Critik der reinen Vernunft. - Königsberg : C. G. Dengel, 1784.

Schütz C. G. Brief an I. Kant vom 13. November 1785// Kant's Gesammelte Schriften. Bd. 10 / I. Kant ; hrsg. von K. P. A. der Wissenschaften. - Berlin : Walter de Gruyter, 1922a. - S. 421-424.

Schütz C. G. Brief an I. Kant vom 18. Februar 1785// Kant's Gesammelte Schriften. Bd. 10 / I. Kant ; hrsg. von K. P. A. der Wissenschaften. - Berlin : Walter de Gruyter, 1922b. - S. 398-400.

Snell C.W. Die Sittlichkeit in Verbindung mit der Glükseligkeit einzelner Menschen und ganzer Staaten, aus zwei gekrönten Preisschriften zusammengezogen, und mit beständiger Rücksicht auf die Kantische Moralphilosophie ganz neu bearbeitet. Frankfurt am Main : Körber, 1790.

Vaihinger H. Commentar zu Kants Kritik der reinen Vernunft. Zum hundertjährigen Jubiläum derselben. Bd. 1. - Stuttgart : W. Spemann, 1881.

Vaihinger H. Die Kantmedaille mit dem schiefen Turm von Pisa // Kant-Studien. 1898. - Jg. 2. - S. 109-115.

Varnhagen K. von Ense. Kant's Leben, von Schubert. 1842. Aus einem Brief an ** in ** // Denkwürdigkeiten und vermischte Schriften. Bd. 5. - Leipzig : F. A. Brockhaus, 1843 . - S. $75^{1-759}$.

Verzeichniss der Münz- und Medaillen-Sammlung [...] Leopold Welzl von Wellenheim. Bd. 2. - Wien : J. P. Sollinger, 1845.

Verzeichniß einer Sammlung vorzüglich schöner und seltener Medaillen und Tahlern, welche in der Michaelis-Messe 1784 allhier zu Leipzig, auf der Clostergasse in der zweyten Etage des Lückschen Hauses,...gegen baare Bezahlung in Conventionsmünze, oder wichtigen Lousd'or und Ducaten verauctioniret werden sollen durch Chr. F. Hecht. - Leipzig : C. P. Dürr, 1784. 
Verzeichniß sämmtlicher Denk- und Gelegenheitsmünzen, welche aus der Berliner Medaillen-Münze von G. Loos, seit der Gründung dieser Anstalt durch den HofMedailleur Daniel Friedrich Loos hervorgegangen sind. - Berlin : S. Mittler, 1842. Von Wolff C. Briefwechsel zwischen Christian Wolff und Ernst Christoph von Manteuffel : 1738-1748. Bd. 1 / hrsg. von J. Stolzenberg, D. Döring, K. Middell. - Hildesheim : Olms, 2019.

Wahrheitliebende Gesellschafft // Grosses vollständiges Universal-Lexicon Aller Wissenschafften und Künste. Bd. $5^{2}$ / hrsg. von J. H. Zedler. - Halle : Zedler, 1747. - S. $947^{-}-954$.

Wasianski E. A. C. Immanuel Kant in seinen letzten Lebensjahren. Ein Beitrag zur Kenntnis seines Charakters und häuslichen Lebens aus dem täglichen Umgange mit ihm // Immanuel Kant. Sein Leben in Darstellungen von Zeitgenossen. Die Biographien von L. E. Borowski, R. B. Jachmann und E. A. Ch. Wasianski / hrsg. von F. Gross, R. Malter. - Darmstadt : Wissenschaftliche Buchhandlung, 1993. - S. 189-271.

Wolff $C$. Le philosophe-roi et le roi-philosophe. La théorie des affaires publiques. Pièces tirèes des oeuvres de Monsieur Chr. Wolff / trad. du latin par J. DesChamps. - Berlin : A. Haude, 1740.

Wuttke H. Ueber Christian Wolff den Philosophen. Eine Abhandlung // Christian Wolffs eigene Lebensbeschreibung / hrsg. von mit einer Abhandlung über Wolff von H. Wuttke. - Leipzig : Weidmann, 1841. - S. 1-80.

Zelter C.F. Brief an J.W. Goethe vom 12. Dezember $1830 / /$ Briefwechsel zwischen Goethe und Zelter in den Jahren 1796 bis 1832. Bd. $6 /$ hrsg. von F. W. Riemer. Berlin : Duncker und Humblot, 1834a. - S. 86-88.

Zelter C.F. Brief an J. W. Goethe vom 2. Dezember $1830 / /$ Briefwechsel zwischen Goethe und Zelter in den Jahren 1796 bis $183^{2}$. Bd. $6 /$ hrsg. von F. W. Riemer. Berlin : Duncker und Humblot, 1834b. - S. 76-79.

Zöllner J.F. Ist es rathsam, das Ehebündniß ferner durch die Religion zu sancieren? // Berlinische Monatsschrift / hrsg. von J. E. Biester. - 1783. - Jg. 2, Nr. 2. - S. $508-517$.

Zöllner J. F. Berichtigung // Intelligenzblatt der allgemeinen Literatur-Zeitung. 1804. - Nr. 99. - S. 800. 
Kruglov, A. N. 2021. "Pamyatnyye i yubileynyye filosofskiye medali kak vizual'noye sredstvo i filosofskiy istochnik [Commemorative and Anniversary Philosophical Medals as a Visual Aid and Philosophical Source]" [in Russian]. Filosofiya. Zhurnal Vysshey shkoly ekonomiki [Philosophy. Journal of the Higher School of Economics] 5 (2), 143-19o.

\section{Aleksey KRUglov}

Doctor of Letters in Philosophy, Professor

Russian State University for the Humanities (Moscow, RUSSia); ORCid: 0000-0002-1152-1309

\section{COMMEMORATIVE AND ANNIVERsaRY PhilosophicAl Medals as a Visual Aid and Philosophical Source}

Submitted: Mar. 22, 2021. Reviewed: Apr. 06, 2021. Accepted: Apr. 15, 2021.

Abstract: The paper demonstrates the significance of commemorative and anniversary philosophical medals that are seen as a special visual aid for problematic issues in the history of philosophy specification. The author puts forward the thesis that such medals can clarify the perception of philosophical doctrine and the context of philosophical doctrine consideration at a particular time. So, they greatly assist as an additional historical and philosophical source, but they can hardly be helpful with the interpretation of either various aspects of a philosophical doctrine or a particular statement of a particular philosopher. The rationale for the thesis presents the analysis of four philosophical medals: the medal commemorating the foundation of the alethophile society (1740), A. Abramson's medal in honor of I. Kant's sixtieth anniversary (1784), A. Abramson's medal for the death of I. Kant (1804), A. L. Held's medals in honor of the sixtieth anniversary of G.W.F. Hegel (1830). If the first three medals contribute to a better understanding of the philosophical traits of the German Enlightenment, the reasons for appealing to Horace's words "sapere aude", Kant's peculiarity as an Enlightenmentist, philosophical meaning of the Kantian Copernican Revolution and the transformation of the perception of the "Critique of Pure Reason" in the late 18th century, expectations regarding the fourth medal has proved misplaced. It cannot clarify the Hegelian phrase about reason as a rose on the cross of modernity and reconciliation with reality. In addition, in the course of clarifying the meaning of the four aforementioned medals, the author also turns to the commemorative medal of Chr. Wolff by J. Dassier (c. 1733), the medal for the return of Chr. Wolff to Halle by J. Chr. Koch (1740) and the medal for Kant's death by F. W. Loos (1804).

Keywords: Commemorative and Anniversary Medals, sapere aude, Kant, Copernican Revolution, "Critique of Pure Reason", Mendelssohn, Owl of Minerva, Hegel.

DOI: $10.17323 / 2587-8719-2021-2-143-190$.

\section{REFERENCES}

Bacon, F. 1972. "O mudrosti drevnikh [De sapiential veterum]" [in Russian]. In vol. 2 of Sochineniya [Works], ed. by A.L. Subbotin, trans. from the Latin by N. A. Fedorov, 223-296. 2 vols. Moskva [Moscow]: Mysl'.

Borowski, L. E. 1993. "Darstellung des Lebens und Charakters Immanuel Kant's" [in German]. In Immanuel Kant. Sein Leben in Darstellungen von Zeitgenossen. Die Biographien von L. E. Borowski, R. B. Jachmann und E. A. Ch. Wasianski, ed. by F. Gross and R. Malter, 1-102. Darmstadt: Wissenschaftliche Buchhandlung. 
Breitinger, J. J. 1736. Artis cogitandi principia ad mentem recentiorum philosophorum compendio exhibita, atque in usum privatae institutionis concinnata [in Latin]. Tiguri: Orell.

Brucker, J. 1748. Bilder-Sal heutiges Tages lebender und durch Gelahrtheit berühmter Schrift-Steller, in welchem derselbigen nach wahren Original-malereyen entworfene Bildnisse in schwarzer Kunst, in natürlicher Aehnlichkeit vorgestellet, und ihre Lebens-umstände, Verdienste um die Wissenschaften und Schriften aus glaubwürdigen Nachrichten erzählet werden [in German]. Vol. 7. Augsburg: Haid.

Denis, M. 1780. Die Merkwürdigkeiten der k. k. garellischen öffentl. Bibliothek am Theresiano [in German]. Wien: Bernhardi.

"Denkmünze auf den Philosophen Kant." 1804 [in German]. Dresdner Anzeigen, no. 45.

"Denkmünze auf den Philosophen Kant." 1804 [in German]. Intelligenzblatt der Jenaischen Allgemeinen Literatur-Zeitung, no. 93: 768.

Dietzsch, S. 2010. "Immanuel Kant im Europa der Aufklärung" [in German]. In Kant der Europäer. Europäer über Kant, ed. by S. Dietzsch, L. Grimoni, and D. Kozlowski, 32-48. Husum: Husum Druck-und Verlagsgesellschaft.

Engelmann, W. 1857. Daniel Chodowieck's sämmtliche Kupferstiche beschrieben, mit historischen, literarischen und bibliographischen Nachweisungen, der Lebensbeschreibung des Künstlers und Registern versehen [in German]. Leipzig: Engelmann.

Essers, V. 1974. "Kant-Bildnisse" [in German]. In Immanuel Kant. Leben-Umwelt-Werk. Ausstellung des Geheimen Staatsarchivs Preußischer Kulturbesitz aus Beständen der Stiftung preußischer Kulturbesitz, der Bayerischen Staatsbibliothek, München, des Hauses Königsberg in Duisburg und anderer Leihgeber zur 250. Wiederkehr von Kants Geburtstag am 22. April 1974, ed. by F. Benninghoven, 39-63. Berlin: Friedrich Benninghoven.

Friedländer, M. 1805. "Geschichte der Münze auf Kant" [in German], ed. by J. E. Biester. Neue Berlinische Monatsschrift 1:398-400.

[Fromm, E.] 1898. "Noch einmal die Kantmedaille mit dem schiefen Turm von Pisa" [in German]. Kant-Studien 2:376-377.

Goethe, J.W. 1828. "Die Geheimnisse" [in German]. In vol. 13 of Goethe's Werke. Vollständige Ausgabe letzter Hand, 179-191. Stuttgart: Gottai'sche Buchhandlung.

- 1834a. "Brief an C. F. Zelter vom 1. Juni 1831" [in German]. In Briefwechsel zwischen Goethe und Zelter in den Jahren 1796 bis 1832, ed. by F. W. Riemer, 6:193-196. Berlin: Duncker und Humblot.

- 1834b. "Brief an C. F. Zelter vom 27. Januar 1832" [in German]. In Briefwechsel zwischen Goethe und Zelter in den Jahren 1796 bis 1832, ed. by F. W. Riemer, 6:382-385. Berlin: Duncker und Humblot.

. 1922. Tayny [Geheimnisse] [in Russian]. Trans. from the German by B. L. Pasternak. Moskva [Moscow]: Sovremennik.

Götten, G.W. 1736. Das Jetzt-lebende Gelehrte Europa, Oder Nachrichten Von den vornehmsten Lebens-Umständen und Schrifften, jetzt lebender Europäischer Gelehrten. Tl. II. [in German]. Braunschweig: Ludolph Schröder.

Gottsched, J. Chr., ed. 1739-1740. Sendschreiben an Gottscheden [in German]. Vol. 5 of Sammlung auserlesener Sendschreiben, welche im 173gten und im Anfange des $1740 t e n$ Jahres an Hrn. Johann Christoph Gottscheden, von vielen gelehrten Männern eingelaufen sind. Dresdner Digitalisierungszentrum.

- 1755. Historische Lobschrift des weiland hoch-und wohlgebohrnen Herrn Christians, Herrn des H.R.R. Freyherrn von Wolf [in German]. Halle: Rengerische Buchhandlung. 
1968. "Das Andenken des vor 100 Jahren in Leipzig gebohrnen Freyherr Gottfried Wilhelms von Leibnitz" [in German]. In vol. 1 of Ausgewählte Werke, ed. by J. Birke, 188-203. Berlin: De Gruyter.

Gottsched, L. A. V. 2012. "Brief an E. Chr. von Manteuffel vom 5. Januar 1740" [in German]. In Auftrage der Sächsischen Akademie der Wissenschaften zu Leipzig hrsg. von D. Döring, M. Rudersdorf, ed. by M. Rudersdorf, 6:285-289. Berlin: De Gruyter.

Grimoni, L., and M. Will, eds. 2004. Immanuel Kant: Erkenntnis-Freiheit-Frieden. Katalog zur Ausstellung anlässlich des 200. Todestages am 12. Februar 2004, Museum Stadt Königsberg der Stadtgemeinschaft Königsberg (Pr.) im Kultur-und Stadthistorischen Museum Duisburg [in German]. Husum: Husum Verlag.

Gulyga, A. V. 1980. Georg Wilhelm Friedrich Hegel [in German]. Trans. by W. Seidel. Leipzig: Reclam.

Hamann, J. G. 1965. "Brief an Johann Georg Scheffner vom 15. März 1784" [in German]. In vol. 5 of Briefwechsel, ed. by W. Ziesemer and A. Henkel, 134. Wiesbaden: Insel Verlag.

Hartknoch, J.F., ed. 1785. "Grundlegung zur Metaphysik der Sitten von Immanuel Kant, 8 Bog. 8" [in German]. Allgemeine Literatur-Zeitung 2 (80): 21-23.

Hasse, J. G. 1804. Letzte Aeußerungen Kant's von einem seiner Tischgenossen [in German]. Königsberg: Nikolovius.

Hegel, G. W. F. 1970. "Kto myslit abstraktno? [Wer denkt abstrakt?]" [in Russian]. In vol. 1 of Raboty raznykh let [Works of Different Years], ed. by A. V. Gulyga, trans. from the German by E. V. Il'yenkov, 387-394. 2 vols. Moskva [Moscow]: Mysl'.

-1975. [in Russian]. Vol. 1 of Filosofiya religii /Vorlesungen über die Philosophie der Religion], ed. by A. V. Gulyga, trans. from the German by M. I. Levina. 2 vols. Moskva [Moscow]: Mysl'.

. 1989a. "Glauben und Wissen oder Reflexionsphilosophie der Subjektivität in der Vollständigkeit ihrer Formen als Kantische, Jacobische und Fichtesche Philosophie" [in German]. In vol. 2 of Werke, ed. by E. Moldenhauer and K. M. Michel, 287-433. 20 vols. Auf der Grundlage der Werke von 1832-1845. Frankfurt am Main: Suhrkamp.

1989b. "Grundlinien der Philosophie des Rechts oder Naturrecht und Staatswissenschaft im Grundrisse" [in German]. In vol. 7 of Werke, ed. by E. Moldenhauer and K. M. Michel, 11-514. 20 vols. Auf der Grundlage der Werke von 1832-1845. Frankfurt am Main: Suhrkamp.

1989c. "Wer denkt abstrakt?" [in German]. In vol. 2 of Werke, ed. by E. Moldenhauer and K. M. Michel, 575-581. 20 vols. Auf der Grundlage der Werke von 1832-1845. Frankfurt am Main: Suhrkamp.

- 1990a. Filosofiya prava [Grundlinien der Philosophie des Rechts] [in Russian]. Trans. from the German by B. G. Stolpner and M. I. Levina. Moskva [Moscow]: Mysl'.

. 1990b. "Vorlesungen über die Philosophie der Religion I" [in German]. In vol. 16 of Werke, ed. by E. Moldenhauer and K. M. Michel, 9-442. 20 vols. Auf der Grundlage der Werke von 1832-1845. Frankfurt am Main: Suhrkamp.

. 2015. "Vorlesungen über die Philosophie des Rechts. Nachschriften zu den Kollegien der Jahre 1821 / 22" [in German]. In vol. 26.2 of Gesammelte Werke, 593-766. Hamburg: Meiner.

. 2016. "Vera i znaniye ili refleksivnaya filosofiya sub"yektivnosti v polnote svoikh form kak filosofiya Kanta, Yakobi i Fikhte [Glauben und Wissen oder Reflexionsphilosophie der Subjektivität in der Vollständigkeit ihrer Formen als Kantische, Jacobische und Fichtesche Philosophie]" [in Russian], trans. from the German by A. A. Ivanenko. ESSE [ESSE]: Filosofskiye $i$ teologicheskiye issledovaniya [Philosophical and Theological Studies] 1 (2): 136-182. 
2017. "Vera i znaniye ili refleksivnaya filosofiya sub"yektivnosti v polnote svoikh form kak filosofiya Kanta, Yakobi i Fikhte [Glauben und Wissen oder Reflexionsphilosophie der Subjektivität in der Vollständigkeit ihrer Formen als Kantische, Jacobische und Fichtesche Philosophie]" [in Russian], trans. from the German by A. A. Ivanenko. ESSE [ESSE]: Filosofskiye $i$ teologicheskiye issledovaniya [Philosophical and Theological Studies] 2 (1): 137-164.

“'Hexalogus Alethophilorum', ili Shest' zakonov Obshchestva lyubiteley istiny ['Hexalogus Alethophilorum', or The Six Laws of the Society of Truth Lovers]." 2011 [in Russian], trans. from the German by K. A. Volkova. Kantovskiy sbornik [Kantian Journal] 37 (3): 91.

Hinske, N. 1995. "Die Kritik der reinen Vernunft und der Freiraum des Glaubens. Zur Kantrezeption des Jenaer Frühkantianismus" [in German]. In Aufklärung und Skepsis. Studien zur Philosophie und Geistesgeschichte des 17. und 18. Jahrhunderts Günter Gawlick zum 65. Geburtstag, ed. by L. Kreimendahl, 231-243. Stuttgart-Bad Cannstatt: Frommann-Holzboog.

- 1999. "'Kritika chistogo razuma' i sfera svobody dlya very. K voprosu o vospriyatii Kanta rannim yyenskim kantianstvom. Razlichnyye vospriyatiya 'Kritiki chistogo razuma' v 1785 godu [Die Kritik der reinen Vernunft und der Freiraum des Glaubens. Zur Kantrezeption des Jenaer Frühkantianismus]" [in Russian]. In Razum i ekzistentsiya. Analiz nauchnykh $i$ vnenauchnykh form myshleniya [Reason and Existence. Analysis of Scientific and Unscientific Forms of Thinking], ed. by I. T. Kasavin and V. N. Porus, trans. by T. I. Oyzerman, 231-244. Sankt-Peterburg [Saint Petersburg]: RKhGI.

Intelligenzblatt der Jenaischen Allgemeinen Literatur-Zeitung. 1804 [in German]. (93).

Jaeschke, W. 2016. Hegel-Handbuch. Leben-Werk-Schule [in German]. Stuttgart: J. B. Metzler.

Juncker, Chr. 1706. Das Guldene und Silberne Ehren-Gedächtniß Des Theuren GottesLehrers D. Martini Lvtheri... [in German]. Frankfurt: Johann Andreä Endters sel. Sohn und Erben.

Kant, I. 1911a. "Kritik der reinen Vernunft" [in German]. In vol. 3 of Kant's Gesammelte Schriften, ed. by Königlich Preußischen Akademie der Wissenschaften, 1-552. Berlin: Georg Reimer.

- 1911b. "Prolegomena zu einer jeden künftigen Metaphysik, die als Wissenschaft wird auftreten können" [in German]. In vol. 4 of Kant's Gesammelte Schriften, ed. by Königlich Preußischen Akademie der Wissenschaften, 253-384. Berlin: Walter de Gruyter.

_. 1913. "Kritik der Urteilskraft" [in German]. In vol. 5 of Kant's Gesammelte Schriften, ed. by Königlich Preußischen Akademie der Wissenschaften, 165-486. Berlin: Georg Reimer.

. 1922a. [in German]. Vol. 13 of Kant's Gesammelte Schriften, ed. by Königlich Preußischen Akademie der Wissenschaften. Berlin: Walter de Gruyter.

. 1922b. "Bestimmung über die Verschenkung der goldenen Kant-Medaille" [in German]. In vol. 12 of Kant's Gesammelte Schriften, ed. by Königlich Preußischen Akademie der Wissenschaften, 392. Berlin: Walter de Gruyter.

. 1922c. "Brief an Chr. G. Schütz vom 13. September 1785" [in German]. In vol. 10 of Kant's Gesammelte Schriften, ed. by Königlich Preußischen Akademie der Wissenschaften, 406-407. Berlin: Walter de Gruyter.

. 1922d. "Brief an J. Schultz vom 4. März 1784" [in German]. In vol. 10 of Kant's Gesammelte Schriften, ed. by Königlich Preußischen Akademie der Wissenschaften, 368-369. Berlin: Walter de Gruyter. 
1922e. "Brief an M. Herz vom 11. Mai 1781" [in German]. In vol. 10 of Kant's Gesammelte Schriften, ed. by Königlich Preußischen Akademie der Wissenschaften, 268-270. Berlin: Walter de Gruyter.

. 1922f. "Brief an M. Mendelssohn vom 16. August 1783" [in German]. In vol. 10 of Kant's Gesammelte Schriften, ed. by Königlich Preußischen Akademie der Wissenschaften, 344-347. Berlin: Walter de Gruyter.

. 1922g. "Ergänzungsstück zum Testament" [in German]. In vol. 12 of Kant's Gesammelte Schriften, ed. by Königlich Preußischen Akademie der Wissenschaften, 391. Berlin: Walter de Gruyter.

- 1923. "Beantwortung der Frage: Was ist Aufklärung?" [In German]. In vol. 8 of Kant's Gesammelte Schriften, ed. by Königlich Preußischen Akademie der Wissenschaften, 35-42. Berlin: Walter de Gruyter.

. 1994a. Kritika chistogo razuma [Kritik der reinen Vernunft] [in Russian]. Trans. from the German by N. O. Losskiy and M. I. Arzakan'yan Ts. G. and Itkin. Moskva [Moscow]: Mysl'.

- 1994b. "Otvet na vopros: Chto takoye prosveshcheniye? [Beantwortung der Frage: Was ist Aufklärung?]" [in Russian]. In Sochineniya na russkom i nemetskom yazykakh [Essays in Russian and German], ed. by N. V. Motroshilova and B. Tushling, trans. from the German by Ts. G. Arzakan'yan, 1:125-147. Moskva [Moscow]: Kami.

- 1994c. "Prolegomeny ko vsyakoy budushchey metafizike, kotoraya mozhet poyavit'sya kak nauka [Prolegomena zu einer jeden künftigen Metaphysik, die als Wissenschaft wird auftreten können]" [in Russian]. In vol. 4 of Sobraniye sochineniy [Collected Works], ed. by A. V. Gulyga, trans. from the German by V. S. Solov'yev, 5-125. 8 vols. Moskva [Moscow]: ChORO.

. 2001. "Kritika sposobnosti suzhdeniya [Kritik der Urteilskraft]" [in Russian]. In Sochineniya na russkom i nemetskom yazykakh [Essays in Russian and German], ed. by N. V. Motroshilova and B. Tushling, trans. from the German by N. V. Motroshilova and T.B. Dlugach, 4:69-833. Moskva [Moscow]: Nauka.

Köhler, J.D. 1740. [in German]. Vol. 12 of Wöchentliche historische Münz-Belustigung, Darinnen allerhand merckwürdige und rare Thaler, Ducaten, Schaustücken, andere sonderbahre Gold-und Silber-Münzen. Nürnberg: Weigel.

- 1741. [in German]. Vol. 13 of Wöchentliche historische Münz-Belustigung, Darinnen allerhand merckwürdige und rare Thaler, Ducaten, Schaustücken, andere sonderbahre Gold-und Silber-Münzen. Nürnberg: Weigel.

Königl. grosbr. genealogischer Kalender auf das Jahr 1780 [in German]. 1780. Lauenburg: Berenberg.

Kotzebue, A. von, ed. 1804a. "Miscellen" [in German]. Der Freimüthige oder Ernst und Scherz, nos. 61-62: 244 .

- ed. 1804b. "Nicht-politische Zeitung No. 30" [in German]. Der Freimüthige oder Ernst und Scherz, no. 172: 168.

Krmnicek, S., and M. Gaidys, eds. 2020. Gelehrtenbilder. Altertumswissenschaftler auf $\mathrm{Me-}$ daillen des 19. Jahrhunderts. Begleitband zur online-Ausstellung im Digitalen Münzkabinett des Instituts für Klassische Archäologie der Universität Tübingen [in German]. Tübingen: Universität Tübingen.

Kundmann, J. Chr. 1741. Die hohen und niedern Schulen Teutschlandes, insonderheit des Hertzogthums Schlesiens, mit ihren Bücher-Vorräthen, in Müntzen, Denen ein Anhang alter rarer goldener Müntzen, so bey Grundgrabung des Hospital-Gebäudes zu Jauer anno 1726 gefunden worden, beygefüget [in German]. Breslau: Johann Jacob Korn. 
"Künste." 1804 [in German]. Intelligenzblatt der allgemeinen Literatur-Zeitung, no. 6o: $482-483$.

Lasson, G. 1909. "Kreuz und Rose. Ein Interpretationsversuch" [in German]. In Beiträge zur Hegel-Forschung, 43-70. Berlin: Trowitzsch.

Laverrenz, C. 1887. [in German]. Vol. 2 of Die Medaillen und Gedächtniszeichen der deutschen Hochschulen. Ein Beitrag zur Geschichte der Universitäten Deutschlands. Berlin: Laverrenz.

Lesser, F.-Chr. 1739. Besondere Müntzen Welche So wohl auf Gelehrte Gesellschafften nemlich Universitäten, Societäten, Seminaria und Gymnasia Als auch Auf gelehrte Leute nemlich Theologos, Jure-Consultos, Medicos und Philosophos, Sonderlich auf den theuren D. Martin Luthern, nach Junchers herausgegebenen güldenen und silbernen Ehren-Gedächtniß Desselben gepräget worden. Mit Kupfern [in German]. Frankfurt: Blochberger.

Lichtenberg, G. Chr. 1844. "Nicolaus Copernicus" [in German]. In Vermischte Schriften, 151-244. Neue vermehrte, von dessen Söhne veranstaltete Original-Ausgabe. Göttingen: Dieterich.

- 1922. "Brief an I. Kant vom 30. Oktober 1791" [in German]. In vol. 11 of Kant's Gesammelte Schriften, by I. Kant, ed. by Königlich Preußischen Akademie der Wissenschaften, 302-303. Berlin: Walter de Gruyter.

- 1994. "Sudelbücher" [in German]. In vol. 1 of Schriften und Briefe, ed. by W. Promies, 7-950. Frankfurt am Main: Zweitausendeins.

- 2007. Vorlesungen zur Naturlehre: Notizen und Materialien zur Experimentalphysik [in German]. Vol. 3, bk. 1 of Gesammelte Schriften. Historisch-kritische und kommentierte Ausgabe, ed. by H. Zehe, A. Krayer, and W. Hinrichs. Göttingen: Wallstein Verlag.

Loew, F. 1828. Ueber das Münzwesen der alten und der neuen Zeit mit angehängten Reductions-Tabellen der dermalen bei den verschiedenen Völkern aller Welttheile geltenden Münzsorten. Aus Original-Quellen bearbeitet [in German]. Regensburg: Loew.

Löwith, K. 2002. Ot Gegelya $k$ Nitsshe. Revolyutsionnyy perelom v myshlenii XIX veka. Marks i K'yerkegor [Von Hegel zu Nietzsche] [in Russian]. Ed. by M. Yermakova and G. Shaposhnikova. Trans. from the German by K. V. Loshchevskiy. Moskva [Moscow]: Vladimir Dal'.

Ludovici, C. G. 1738. [in German]. Vol. 1 of Ausführlicher Entwurf einer vollständigen Historie der Wolffischen Philosophie. 3 vols. Leipzig: Löwe.

Luther, M. 1934. "Brief an L. Spengler vom 8. Juli 1530" [in German]. In vol. 5 of Dr. Martin Luthers Werke. Kritische Gesamtausgabe. Briefwechsel, 445. Weimar: Hermann Böhlaus Nachfolger.

Mendelssohn, M. 1786. [in German]. Vol. 1 of Morgenstunden oder Vorlesungen über das Daseyn Gottes. Berlin: Voss.

- 1922. "Brief an I. Kant vom 10. April 1783" [in German]. In vol. 10 of Kant's Gesammelte Schriften, by I. Kant, ed. by Königlich Preußischen Akademie der Wissenschaften, 307-308. Berlin: Walter de Gruyter.

. 1977. "Brief an M. Herz vom 18. November 1783" [in German]. In vol. 13 of Gesammelte Schriften. Jubiläumsausgabe, ed. by I. u. a. Elbogen, 160-161. Stuttgart-Bad Cannstatt: Frommann-Holzboog.

- 2011. "Chto znachit prosveshchat'? [Ueber die Frage]" [in Russian], trans. from the German by K. A. Volkova. Kantovskiy sbornik [Kantian Journal] 37 (3): 74-78.

Meusel, J.G. 1808. [in German]. Vol. 1 of Teutsches Künstlerlexikon oder Verzeichnis der jetztlebenden teutschen Künstler. Nebst einem Verzeichniss sehenswürdiger Bib- 
liotheken, Kunst-Münz-und Naturalienkabinete in Teutschland und in der Schweiz. Lemgo: Meyer.

[Mortzfeld, J. Chr.] 1802. Fragmente aus Kants Leben. Ein biographischer Versuch [in German]. Königsberg: Hering und Haberland.

Nachricht von der zu Berlin auf der Gesellschaft der Alethophilorum oder Liebhaber der Wahrheit geschlagenen Müntze [in German]. 1740. Berlin: Haude.

Nilsson, H. 2013. Erik Wallers samling av medicinhistoriska medaljer. Uppsala: Uppsala Universitet.

Noack, L., ed. 1858. "Immanuel Kant und seine Geistesthat" [in German]. In vol. 1 of Psyche. Zeitschrift für die Kenntnis des menschlichen Seelen-und Geisteslebense, 1-45. Herausgeber: FB\&C Ltd.

Plathow, M. 2014. Vor Gott in der Welt. Luthers neues Wirklichkeitsverständnis [in German]. Berlin: Lit Verlag.

Pollard, G, ed. 1967. Renaissance Medals from the Samuel H. Kress Collection at the National Gallery of Art Based on the Catalogue of Renaissance Medals in the Gustave Dreyfus Collection. London: Phaidon Press.

Quintus Horatius Flaccus. 1993. "' [in Russian]. In Sobraniye sochineniy [Complete Works], ed. by S. V. Chistobayev, trans. from the Latin by N. S. Gintsburg, 289-342. Sankt-Peterburg [Saint Petersburg]: Biograficheskiy institut Studiya biografika.

- 2008-. 2016. "' [in Russian]. Horatius. Accessed Mar. 18, 2021. https://www.horati us.ru/index.xps?3.902.

Rambach, F.E., ed. 1760. Johann Peter Nicerons Nachrichten von den Begebenheiten und Schriften berümter Gelehrten mit einigen Zusätzen [in German]. Halle: Verlag und Druck Christoph Peter Franckens.

Reiche, C. Chr., ed. 1783. Berichte der allgemeinen Buchhandlung der Gelehrten vom Jahr 1783 [in German]. Leipzig: Buchhandlung.

Reicke, R., ed. 1860. Kantiana. Beiträge zu Immanuel Kants Leben und Schriften [in German]. Theile: Königsberg.

Rizzini, P. 1892. Illustrazione dei civici musei di Brescia [in Italian]. Brescia: F. Apollonio.

Rosenkranz, K. 1840. "Geschichte der Kant'schen Philosophie" [in German]. In vol. 12 of Immanuel Kant's Sämmtliche Werke, ed. by K. Rosenkranz and F. W. Schubert, 1-498. Leipzig: Voss.

Schelling, F. W. J. 1989. "Immanuil Kant [Immanuel Kant]" [in Russian]. In vol. 2 of Sochineniya [Collected Works], ed. by A. V. Gulyga, trans. from the German by M. I. Levina and A. V. Mikhaylov, 27-33. 2 vols. Moskva [Moscow]: Mysl'.

Schelling, F. W. J. von. 186o. "Immanuel Kant" [in German]. In vol. 6 of Sämmtliche Werke, 1-10. Stuttgart, Augsburg: Cotta.

Schiller, F. 1795. "Ueber die ästhetische Erziehung des Menschen in einer Reyhe von Briefen" [in German]. In vol. 1 of Die Horen, ed. by F. Schiller, 7-48. Tübingen: J. G. Cottaische Buchhandlung.

- 1957. "Pis'ma ob esteticheskom vospitanii cheloveka [Ueber die ästhetische Erziehung des Menschen in einer Reyhe von Briefen]" [in Russian]. In vol. 6 of Sobraniye sochineniy [Collected Works], ed. by N. N. Vil'mont and R. M. Samarin, trans. from the German by E. L. Radlov, 251-358. 7 vols. Moskva [Moscow]: Gosudarstvennoye izdatel'stvo khudozhestvennoy literatury.

Schneiders, W. 1990. Hoffnung auf Vernunft. Aufklärungsphilosophie in Deutschland [in German]. Hamburg: Meiner.

Scholz, O. 2014. "'Erscheinet doch endlich, ihr güldenen Zeiten! / Da Weisheit und Tugend die Menschen regiert.' - Johann Christoph Gottsched als Aufklärer" [in German]. In Jo- 
hann Christoph Gottsched (170o-1766): Philosophie, Poetik und Wissenschaft, ed. by E. Achermann, 27-38. Berlin: Akademie Verlag.

Schorn, L., ed. 1832. [in German]. Vol. 1 of Leben der ausgezeichnetsten Maler, Bildhauer und Baumeister von Cimabue bis zum Jahre 1567, beschrieben von Giorgio Vasari, aus dem Italienischen. Stuttgart: B. c.

Schröpfer, H. 2003. Kants Weg in die Öffentlichkeit: Christian Gottfried Schütz als Wegbereiter der kritischen Philosophie [in German]. Stuttgart-Bad Cannstatt: Frommann-Holzboog.

Schubert, F.W. 1842. "Immanuel Kant's Biographie" [in German]. In vol. 11 of Immanuel Kant's Sämmtliche Werke, ed. by K. Rosenkranz and F. W. Schubert, 1-220. Leipzig: Voss.

Schuchardt, Chr., ed. 1848. Goethe's Kunstsammlungen. Tl. 2: Geschnittene Steine, Bronzen, Medaillen, Münzen; Arbeiten in Marmor, Elfenbein und Holz; antike Vasen und Terracotten, Gypsabgüsse, Majolica u. A. [in German]. Jena: Friedrich Frommann.

Schultz [Schulze], J. 1784. Erläuterungen über des Herrn Professor Kant Critik der reinen Vernunft [in German]. Königsberg: C. G. Dengel.

Schulze, I. 2010. Raz"yasnyayushcheye izlozheniye "Kritiki chistogo razuma" [Erläuterungen über des Herrn Professor Kant Critik der reinen Vernunft]: Rukovodstvo dlya chteniya [in Russian]. Trans. from the German by B. A. Fokht. Moskva [Moscow]: URSS.

Schütz, Chr. G. 1922a. "Brief an I. Kant vom 13. November 1785" [in German]. In vol. 10 of Kant's Gesammelte Schriften, by I. Kant, ed. by Königlich Preußischen Akademie der Wissenschaften, 421-424. Berlin: Walter de Gruyter.

- 1922b. "Brief an I. Kant vom 18. Februar 1785" [in German]. In vol. 10 of Kant's Gesammelte Schriften, by I. Kant, ed. by Königlich Preußischen Akademie der Wissenschaften, 398-400. Berlin: Walter de Gruyter.

Snell, Chr. W. 1790. Die Sittlichkeit in Verbindung mit der Glükseligkeit einzelner Menschen und ganzer Staaten, aus zwei gekrönten Preisschriften zusammengezogen, und mit beständiger Rücksicht auf die Kantische Moralphilosophie ganz neu bearbeitet [in German]. Frankfurt am Main: Körber.

Speler, R.-T., ed. 1994. 300 Jahre Universität Halle 1694-1994. Schätze aus den Sammlungen und Kabinetten Halle [in German]. Halle: Ed. Stekofoto.

Vaihinger, H. 1881. [in German]. Vol. 1 of Commentar zu Kants Kritik der reinen Vernunft. Zum hundertjährigen Jubiläum derselben. Stuttgart: W. Spemann.

- 1898. "Die Kantmedaille mit dem schiefen Turm von Pisa" [in German]. Kant-Studien 2:109-115.

Varnhagen, K. A. von Ense. 1843. "Kant's Leben, von Schubert. 1842. Aus einem Brief an ** in **" [in German]. In vol. 5 of Denkwürdigkeiten und vermischte Schriften, 751-759. Leipzig: F. A. Brockhaus.

Verzeichniß einer Sammlung vorzüglich schöner und seltener Medaillen und Tahlern, welche in der Michaelis-Messe 1784 allhier zu Leipzig, auf der Clostergasse in der zweyten Etage des Lückschen Hauses,...gegen baare Bezahlung in Conventionsmünze, oder wichtigen Lousd'or und Ducaten verauctioniret werden sollen durch Chr. F. Hecht [in German]. 1784. Leipzig: C. P. Dürr.

Verzeichniß sämmtlicher Denk-und Gelegenheitsmünzen, welche aus der Berliner Medaillen-Münze von G. Loos, seit der Gründung dieser Anstalt durch den Hof-Medailleur Daniel Friedrich Loos hervorgegangen sind [in German]. 1842. Berlin: S. Mittler.

Von Wolff, Christian. 2019. Briefwechsel zwischen Christian Wolff und Ernst Christoph von Manteuffel: 1738-1748 [in German]. Ed. by J. Stolzenberg, D. Döring, and K. Middell. Vol. 1. Hildesheim: Olms. 
Wasianski, E. A. Chr. 1993. "Immanuel Kant in seinen letzten Lebensjahren. Ein Beitrag zur Kenntnis seines Charakters und häuslichen Lebens aus dem täglichen Umgange mit ihm" [in German]. In Immanuel Kant. Sein Leben in Darstellungen von Zeitgenossen. Die Biographien von L. E. Borowski, R. B. Jachmann und E. A. Ch. Wasianski, ed. by F. Gross and R. Malter, 189-271. Darmstadt: Wissenschaftliche Buchhandlung.

Weber, W., ed. 1870. [in German]. Vol. 5 of Berliner Blätter für Münz-, Siegel-und Wappenkunde. Berlin: W. Weber.

Wolff, Chr. 1740. Le philosophe-roi et le roi-philosophe. La théorie des affaires publiques. Pièces tirèes des oeuvres de Monsieur Chr. Wolff [in French]. Trans. from the Latin by J. Des-Champs. Berlin: A. Haude.

Wuttke, H. 1841. "Ueber Christian Wolff den Philosophen. Eine Abhandlung" [in German]. In Christian Wolffs eigene Lebensbeschreibung, ed. by mit einer Abhandlung über Wolff von $\mathrm{H}$. Wuttke, 1-80. Leipzig: Weidmann.

Zedler, J. H., ed. 1747. "Wahrheitliebende Gesellschafft" [in German]. In vol. 52 of Grosses vollständiges Universal-Lexicon Aller Wissenschafften und Künste, 947-954. Halle: Zedler.

Zelter, C.F. 1834a. "Brief an J.W. Goethe vom 12. Dezember 1830" [in German]. In vol. 6 of Briefwechsel zwischen Goethe und Zelter in den Jahren 1796 bis 1832, ed. by F. W. Riemer, 86-88. Berlin: Duncker und Humblot.

- 1834b. "Brief an J.W. Goethe vom 2. Dezember 1830" [in German]. In vol. 6 of Briefwechsel zwischen Goethe und Zelter in den Jahren 1796 bis 1832, ed. by F. W. Riemer, 76-79. Berlin: Duncker und Humblot.

Zöllner, J.F. 1783. "Ist es rathsam, das Ehebündniß ferner durch die Religion zu sancieren?" [in German], ed. by J.E. Biester. Berlinische Monatsschrift 2 (2): 508-517.

. 1804. "Berichtigung" [in German]. Intelligenzblatt der allgemeinen Literatur-Zeitung, no. 99: 800 . 